

\section{Twelve-Month Evaluation of UPS Diesel Hybrid Electric Delivery Vans}

M. Lammert

Prepared under Task No. FC08.3000
Technical Report NREL/TP-540-44134

December 2009



National Renewable Energy Laboratory 1617 Cole Boulevard, Golden, Colorado 80401-3393 303-275-3000 • www.nrel.gov

NREL is a national laboratory of the U.S. Department of Energy Office of Energy Efficiency and Renewable Energy

Operated by the Alliance for Sustainable Energy, LLC

Contract No. DE-AC36-08-G028308 


\section{NOTICE}

This report was prepared as an account of work sponsored by an agency of the United States government. Neither the United States government nor any agency thereof, nor any of their employees, makes any warranty, express or implied, or assumes any legal liability or responsibility for the accuracy, completeness, or usefulness of any information, apparatus, product, or process disclosed, or represents that its use would not infringe privately owned rights. Reference herein to any specific commercial product, process, or service by trade name, trademark, manufacturer, or otherwise does not necessarily constitute or imply its endorsement, recommendation, or favoring by the United States government or any agency thereof. The views and opinions of authors expressed herein do not necessarily state or reflect those of the United States government or any agency thereof.

Available electronically at http://www.osti.gov/bridge

Available for a processing fee to U.S. Department of Energy and its contractors, in paper, from:

U.S. Department of Energy

Office of Scientific and Technical Information

P.O. Box 62

Oak Ridge, TN 37831-0062

phone: 865.576 .8401

fax: 865.576 .5728

email: mailto:reports@adonis.osti.gov

Available for sale to the public, in paper, from:

U.S. Department of Commerce

National Technical Information Service

5285 Port Royal Road

Springfield, VA 22161

phone: 800.553.6847

fax: 703.605.6900

email: orders@ntis.fedworld.gov

online ordering: http://www.ntis.gov/ordering.htm 


\section{Acknowledgments}

This evaluation is funded through the Advanced Vehicle Testing Activity, which is managed by Lee Slezak within the U.S. Department of Energy (DOE) Office of Energy Efficiency and Renewable Energy. All publications regarding the United Parcel Service (UPS) hybrid delivery van evaluation will be posted on DOE's Energy Efficiency and Renewable Energy Web site. See the Medium- and Heavy-Duty Vehicles section at the following link:

http://www1.eere.energy.gov/vehiclesandfuels/avta/index.html.

This evaluation, conducted at UPS, would not have been possible without the support and cooperation of many people. The author wishes to thank each of the following:

U.S. Department of Energy

Lee Slezak

UPS

Robert K. Hall

Bill Brentar

Eaton Corporation

Alex Stuckey 


\section{List of Acronyms and Abbreviations}

$\begin{array}{ll}\text { AVTA } & \text { Advanced Vehicle Testing Activity } \\ \text { bhp } & \text { brake horsepower } \\ \text { CO } & \text { carbon monoxide } \\ \mathrm{CO}_{2} & \text { carbon dioxide } \\ \text { DOE } & \text { U.S. Department of Energy } \\ \text { EGR } & \text { exhaust gas recirculation } \\ \text { FT\&E } & \text { Fleet Test and Evaluation (NREL team) } \\ \text { g/bhp-hr } & \text { grams per brake horsepower hour } \\ \text { GPS } & \text { global positioning system } \\ \text { GVWR } & \text { gross vehicle weight rating } \\ \text { HC } & \text { hydrocarbon } \\ \text { HVAC } & \text { heating, ventilation, and air conditioning } \\ \text { mpg } & \text { miles per gallon } \\ \text { mph } & \text { miles per hour } \\ \text { MY } & \text { model year } \\ \text { NOx } & \text { oxides of nitrogen } \\ \text { NREL } & \text { National Renewable Energy Laboratory } \\ \text { PM } & \text { particulate matter } \\ \text { ppm } & \text { parts per million } \\ \text { ReFUEL } & \text { Renewable Fuels and Lubricants (Laboratory) } \\ \text { rpm } & \text { revolutions per minute } \\ \text { THC } & \text { total hydrocarbons } \\ \text { ULSD } & \text { ultra-low-sulfur diesel } \\ \text { UPS } & \text { United Parcel Service } \\ \text { VDC } & \text { voltage direct current } \\ & \end{array}$




\section{Executive Summary}

This 12-month evaluation is part of a series of evaluations from the U.S. Department of Energy (DOE). Using an established and documented evaluation protocol, DOEthrough the National Renewable Energy Laboratory (NREL) - has been tracking and evaluating new propulsion systems in transit buses and trucks for more than 10 years. The DOE/NREL vehicle evaluations are a part of the Advanced Vehicle Testing Activity (AVTA), which supports DOE's Vehicle Technologies Program.

The role of AVTA is to bridge the gap between research and development and the commercial availability of advanced vehicle technologies that reduce petroleum use in the United States and improve air quality. The main objective of AVTA projects is to provide comprehensive, unbiased evaluations of advanced vehicle technologies in commercial use. Data are collected and analyzed for operation, maintenance, performance, costs, and emissions characteristics of both advanced-technology fleets and comparable conventional-technology fleets that are operating at the same site. AVTA evaluations enable fleet owners and operators to make informed vehicle-purchasing decisions.

This report focuses on a parallel hybrid-electric diesel delivery van propulsion system currently being operated by United Parcel Service (UPS). The propulsion system is an alternative to the standard diesel system and could enable reductions in emissions, primarily particulate matter and oxides of nitrogen $\left(\mathrm{NO}_{\mathrm{x}}\right)$, as well as reductions in petroleum use. Hybrid propulsion allows for increased fuel economy, which ultimately reduces petroleum use.

\section{Evaluation Design}

This 12-month evaluation used six P70H hybrids and six P70D standard diesels that are located in two UPS facilities in the Phoenix, Arizona, area. Dispatch and maintenance practices are the same at both facilities. GPS logging, fueling, and maintenance records are used to evaluate the performance of these hybrid step delivery vans.

In addition, a P100H hybrid and a P100D standard diesel were tested at NREL's Renewable Fuels and Lubricants (ReFUEL) Research Laboratory. Testing was performed over multiple standard drive cycles - the Combined International Local and Commuter Cycle, the West Virginia University City cycle, and the Central Business District cycleto evaluate the fuel economy and emissions benefits gained through hybridization. The P100 chassis and engine combination is different from the one used in the P70 and has a higher gross vehicle weight (GVW), but it uses the same hybrid system as the P70's.

\section{Evaluation Results}

The results and related discussions included here focus only on the selected facilities, the two P70 study groups, and the two P100 vehicles tested at the ReFUEL lab.

\section{Delivery Van Use and Duty Cycle}

The hybrids had an average monthly mileage rate that was $20 \%$ less than that of the diesel vans. The hybrids consistently were driven a fewer number of miles throughout the 
evaluation period, but they also experienced extended downtime late in the year as a result of an accident and calibration issues. The hybrids spent more time idling and operating at slower speeds than the diesels did, and the diesels spent slightly more time operating at greater speeds; this accounted for much of the hybrids' fewer monthly miles.

\section{Fuel Economy}

The 12-month average fuel economy for the hybrid vans is $13.1 \mathrm{mpg}, 28.9 \%$ greater than the diesel van group's $10.2 \mathrm{mpg}$. Figure ES-1 shows the average monthly miles per gallon for each van group and the cumulative average miles per gallon, as well.

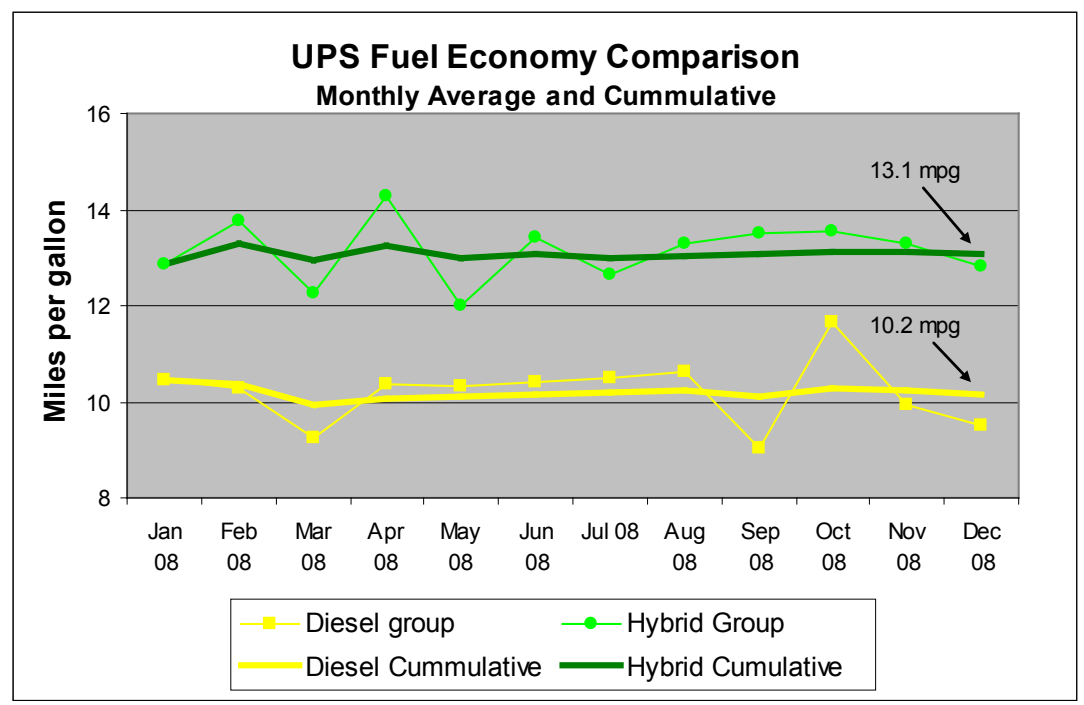

Figure ES-1. Average monthly and cumulative fuel economy

\section{Maintenance Costs}

The total maintenance cost per mile of $\$ 0.140$ for the hybrid vans was $8 \%$ less than the $\$ 0.152$ for the diesel vans. The propulsion-related maintenance cost per mile of $\$ 0.034$ for the hybrid vans was $5 \%$ less than the $\$ 0.036$ for the diesel vans. Using a t-test, researchers found neither difference to be statistically significant.

\section{Reliability}

The hybrid group had a cumulative average of $95.5 \%$ uptime over the 12 -month study period, less than the diesel group's cumulative average of $99.3 \%$ uptime. The hybrids experienced troubleshooting and recalibration issues related to prototype components that are primarily responsible for the lower uptime figures.

\section{Laboratory Fuel Economy and Emissions Testing}

The P100 hybrid vans consistently showed a 31\%-37\% fuel economy improvement over the conventional P100 vans on the three tested duty cycles. The hybrid vans showed improvement in some emissions, but the results varied significantly depending on the cycle being run. The hybrid vans showed an increase in $\mathrm{NO}_{\mathrm{x}}$ for all cycles. 


\section{Table of Contents}

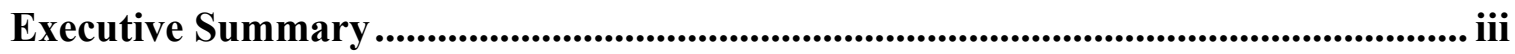

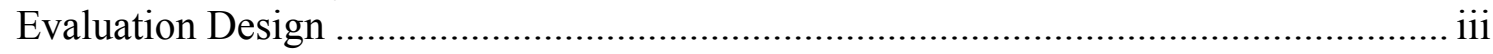

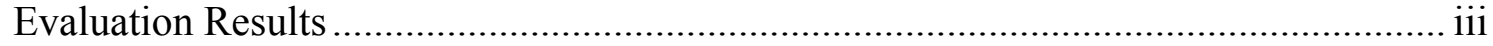

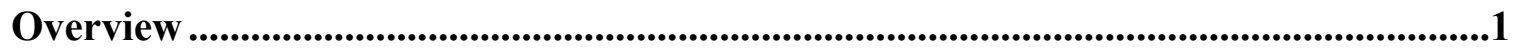

Advanced Vehicle Testing Activity ........................................................................... 1

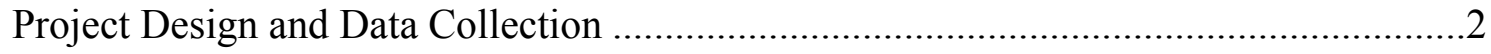

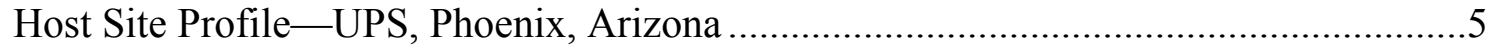

Evaluation Results .........................................................................................................5

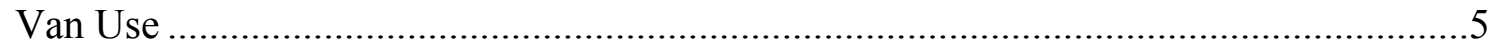

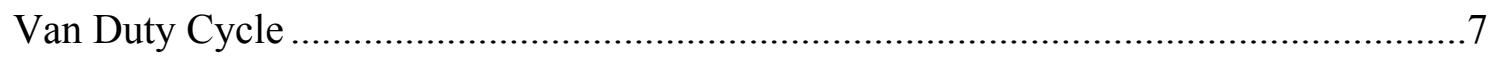

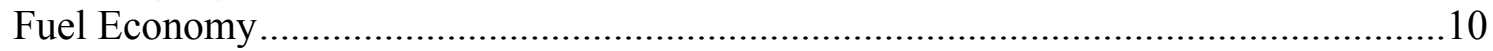

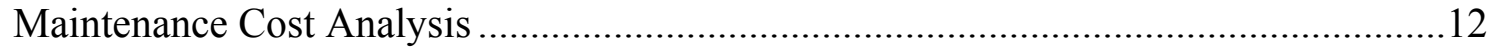

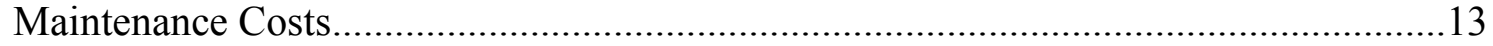

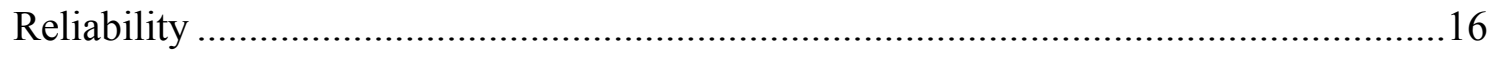

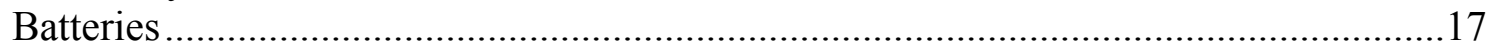

Laboratory Fuel Economy and Emissions Testing ................................................18

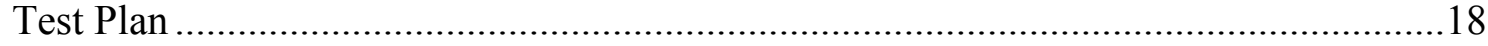

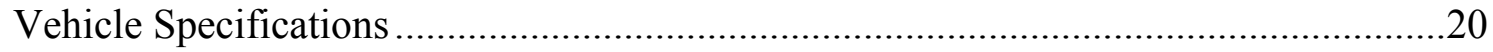

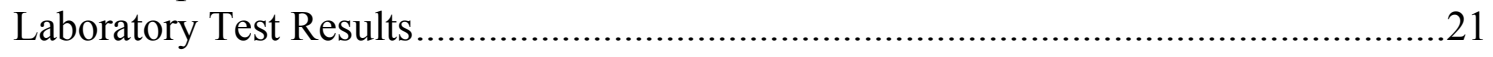

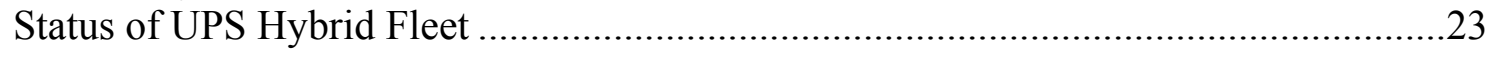

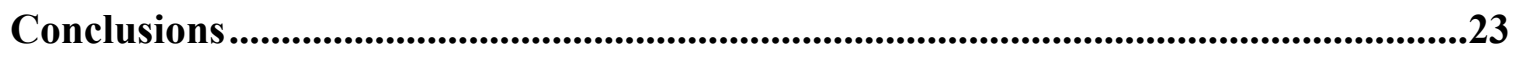

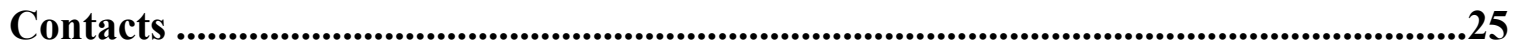

Appendix: Laboratory Description and Test Methods ..................................................26

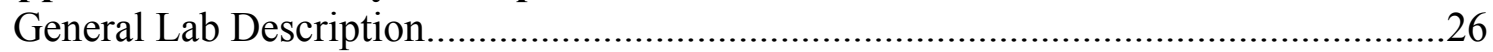

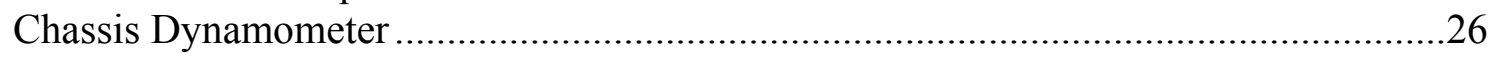

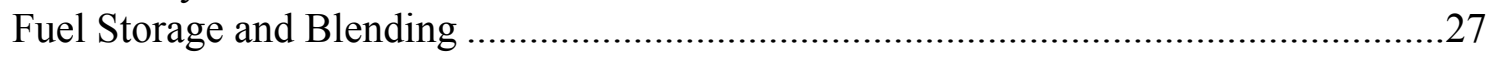

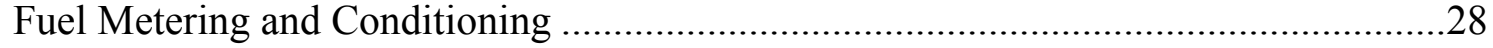

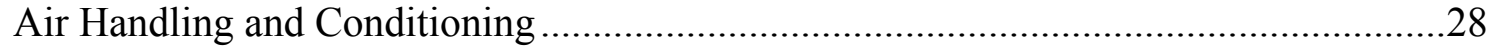

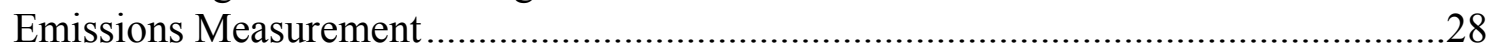




\section{Overview}

\section{Advanced Vehicle Testing Activity}

The role of the Advanced Vehicle Testing Activity (AVTA) is to help bridge the gap between research and development (R\&D) and commercial availability for advanced vehicle technologies that reduce petroleum use and meet air-quality standards. AVTA supports the U.S. Department of Energy's (DOE) Vehicle Technologies Program by examining market factors and customer requirements and evaluating the performance and durability of alternative-fuel and advancedtechnology vehicles in fleet applications. The National Renewable Energy Laboratory's (NREL) Fleet Test and Evaluation (FT\&E) team conducts evaluations primarily with support from AVTA, but also with support from other DOE programs focused on non-petroleum-based and advanced petroleum-based fuels.

The main objective of FT\&E projects is to conduct comprehensive, unbiased evaluations of advanced-technology vehicles. Data collected and analyzed include the operations, maintenance, performance, cost, and emissions characteristics of advanced-technology vehicles and comparable conventional technology in fleets operating at the same site. The FT\&E evaluations help fleet owners and operators make informed vehicle-purchasing decisions. The evaluations also provide valuable data to DOE about the maturity of the technology being assessed.

The FT\&E team has been conducting several evaluations of advanced-propulsion heavy-duty vehicles (see Table 1). Information on these and other evaluations involving advanced technologies or alternative fuels, such as biodiesel and Fischer-Tropsch diesel, is available at www.nrel.gov/vehiclesandfuels/fleettest.

Table 1. FT\&E Heavy-Duty Vehicle Evaluations

\begin{tabular}{|c|c|c|c|c|}
\hline Fleet & Location & Vehicle & Technology & Evaluation Status \\
\hline $\begin{array}{l}\text { Long Beach } \\
\text { Transit }\end{array}$ & $\begin{array}{l}\text { Long Beach, } \\
\text { CA }\end{array}$ & $\begin{array}{l}\text { New Flyer } 40-\mathrm{ft} \text { low } \\
\text { floor transit bus }\end{array}$ & Gasoline-electric series hybrid & $\begin{array}{l}\text { Completed in June } \\
2008\end{array}$ \\
\hline Metro & St. Louis, MO & $\begin{array}{l}\text { GILLIG 40-ft transit } \\
\text { bus }\end{array}$ & Biodiesel blend (B20) & $\begin{array}{l}\text { Completed in July } \\
2008\end{array}$ \\
\hline $\begin{array}{l}\text { New York } \\
\text { City Transit }\end{array}$ & $\begin{array}{l}\text { Manhattan, NY; } \\
\text { Bronx, NY }\end{array}$ & $\begin{array}{l}\text { Orion VII 40-ft transit } \\
\text { bus }\end{array}$ & $\begin{array}{l}\text { Series hybrid, BAE Systems } \\
\text { HybriDrive }{ }^{\circledR} \text { propulsion system } \\
\text { (diesel), order of } 200 \text { (Gen II); } \\
\text { order of } 125 \text { (Gen I) }\end{array}$ & $\begin{array}{l}\text { Completed in } \\
\text { January } 2008\end{array}$ \\
\hline $\begin{array}{l}\text { New York } \\
\text { City Transit }\end{array}$ & $\begin{array}{l}\text { Manhattan, NY; } \\
\text { Bronx, NY }\end{array}$ & $\begin{array}{l}\text { Orion VII 40-ft transit } \\
\text { bus }\end{array}$ & $\begin{array}{l}\text { Series hybrid, BAE Systems } \\
\text { HybriDrive }{ }^{\circledR} \text { propulsion system } \\
\text { (diesel), order of 125; DDC S50G } \\
\text { CNG engines }\end{array}$ & $\begin{array}{l}\text { Completed in } \\
\text { November } 2006\end{array}$ \\
\hline Denver RTD & Boulder, CO & $\begin{array}{l}\text { GILLIG 40-ft transit } \\
\text { bus }\end{array}$ & Biodiesel blend (B20) & $\begin{array}{l}\text { Completed in } \\
\text { October } 2006\end{array}$ \\
\hline $\begin{array}{l}\text { King County } \\
\text { Metro }\end{array}$ & Seattle, WA & $\begin{array}{l}\text { New Flyer } 60-\mathrm{ft} \\
\text { articulated transit bus }\end{array}$ & $\begin{array}{l}\text { Parallel hybrid, GM-Allison E }{ }^{\top} 50 \\
\text { System (diesel) }\end{array}$ & $\begin{array}{l}\text { Completed in } \\
\text { December } 2006\end{array}$ \\
\hline IndyGo & Indianapolis, IN & Ebus 22-ft bus & $\begin{array}{l}\text { Series hybrid, Capstone } \\
\text { MicroTurbine (diesel) }\end{array}$ & Completed in 2005 \\
\hline $\begin{array}{l}\text { Knoxville } \\
\text { Area Transit }\end{array}$ & Knoxville, TN & Ebus 22-ft bus & $\begin{array}{l}\text { Series hybrid, Capstone } \\
\text { MicroTurbine (propane) }\end{array}$ & Completed in 2005 \\
\hline Norcal & $\begin{array}{l}\text { San Francisco, } \\
\text { CA }\end{array}$ & $\begin{array}{l}\text { Peterbilt/378, } \\
\text { Class } 8 \text { truck }\end{array}$ & $\begin{array}{l}\text { Cummins Westport ISXG high- } \\
\text { pressure, direct- injection, lique- } \\
\text { fied natural gas (LNG) and diesel }\end{array}$ & Completed in 2004 \\
\hline
\end{tabular}




\section{Project Design and Data Collection}

This report discusses a 12-month evaluation of six model year (MY) 2007 Freightliner P70H hybrids that were placed in service in Phoenix, Arizona, during the second half of 2007. These hybrid vehicles are evaluated against six MY 2006 Freightliner P70D diesels that were placed in service in Estrella, Arizona, during the first months of 2007. The diesel vans were chosen by using UPS's database and comparing the average miles per day of the six hybrids to that of diesel vans that had the same size and cargo capability and that were located at the two facilities. All fueling and maintenance data are collected by UPS from its databases and were shared with NREL for this evaluation.

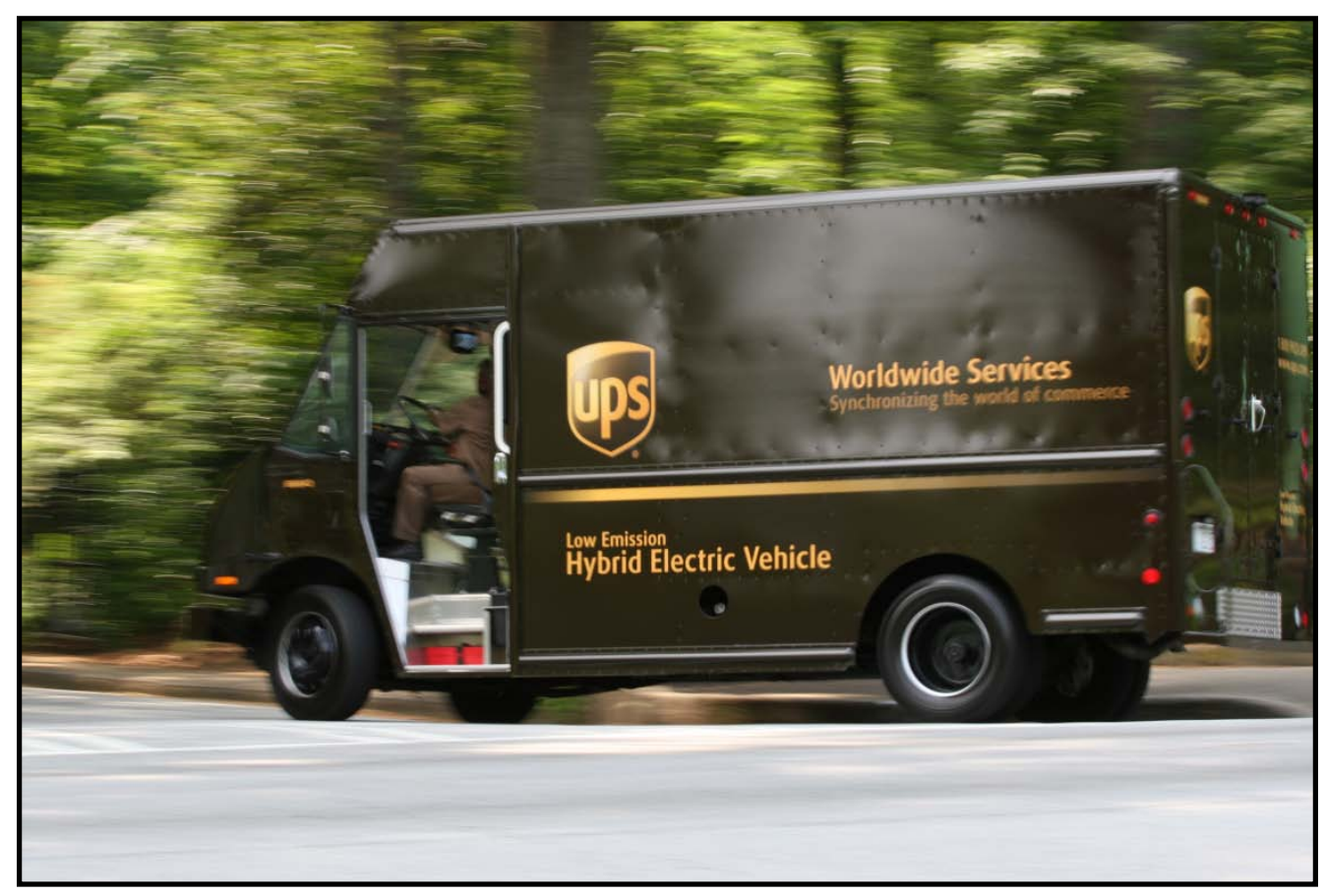

Figure 1. UPS hybrid van

Table 2 presents additional details on Eaton Corporation's parallel hybrid system, and Figure 2 provides a schematic of the system.

Table 2. Hybrid Propulsion-Related Systems

\begin{tabular}{|l|l|}
\hline \multicolumn{1}{|c|}{ Category } & \multicolumn{1}{c|}{ Hybrid Van Description } \\
\hline Manufacturer/integrator & Eaton Corporation \\
\hline \multirow{3}{*}{ Transmission } & Fuller medium-duty automated manual \\
& 6-speed \\
& Prototype \\
\hline \multirow{3}{*}{ Motor } & Synchronous brushless, permanent magnet \\
& Continuous power, 26 kW \\
& Peak power, 44 kW \\
\hline \multirow{3}{*}{ Energy storage } & Lithium ion batteries \\
& $340 \mathrm{VDC}$ \\
& $1.8 \mathrm{kWh}$ total storage \\
\hline
\end{tabular}




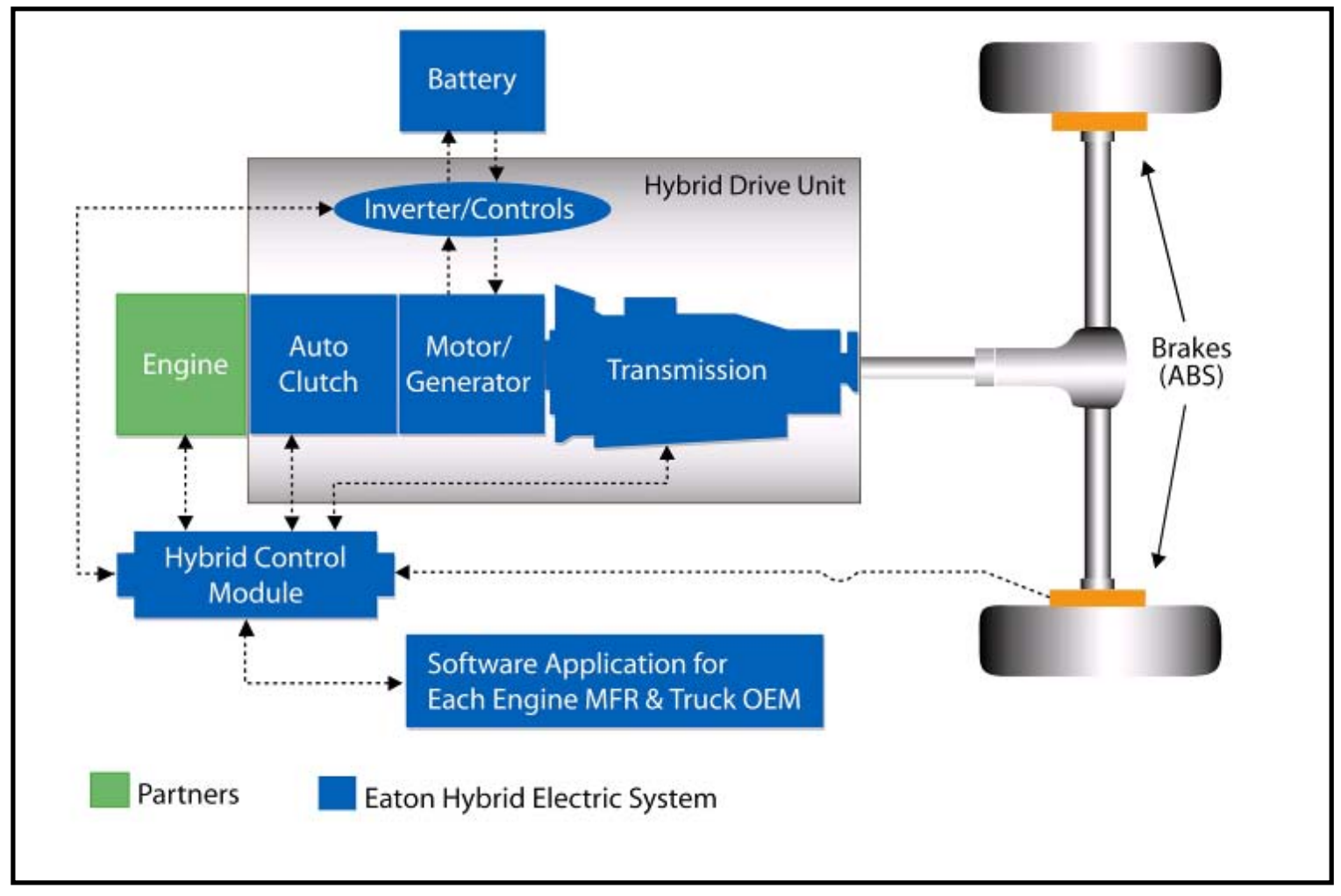

Figure 2. Eaton hybrid system schematic

Figure 3 shows the primary hybrid components in the Eaton system.

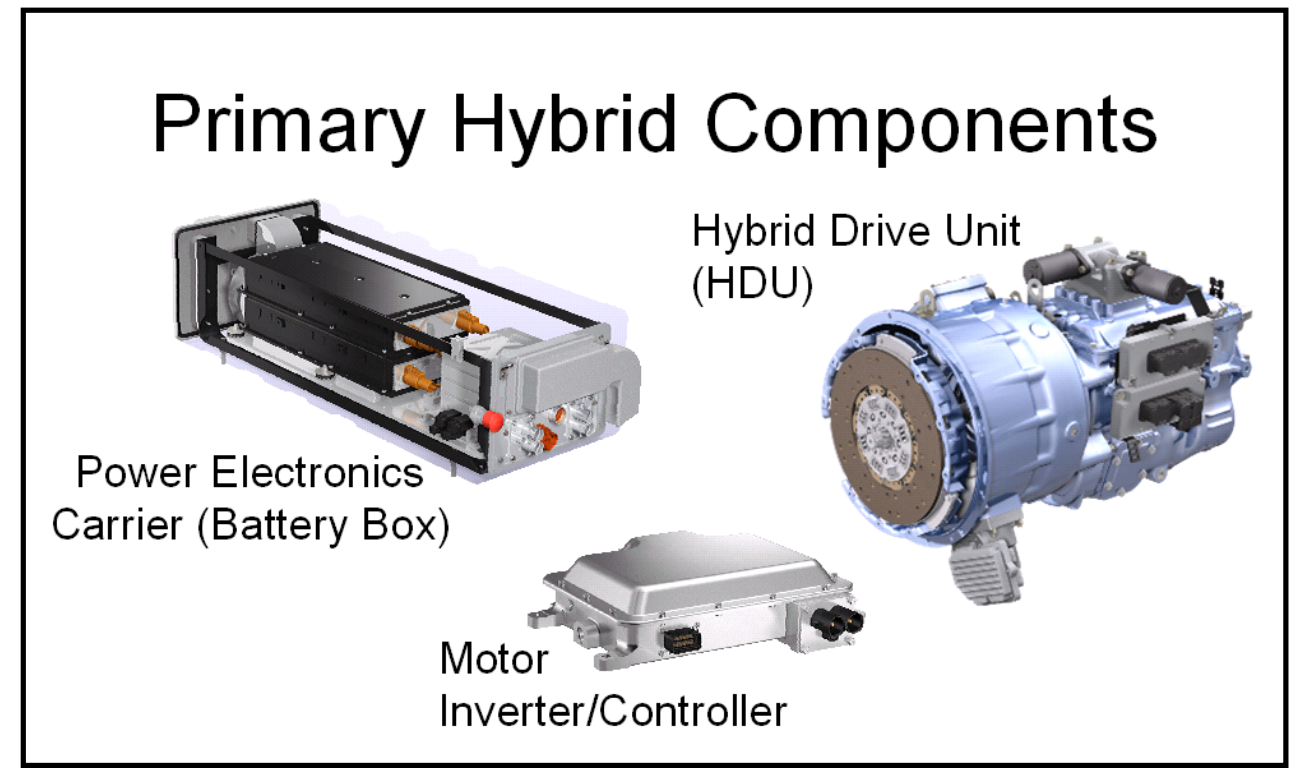

Figure 3. Eaton hybrid system components

Figure 4 shows the primary hybrid components arranged in the undercarriage of a UPS delivery van. 


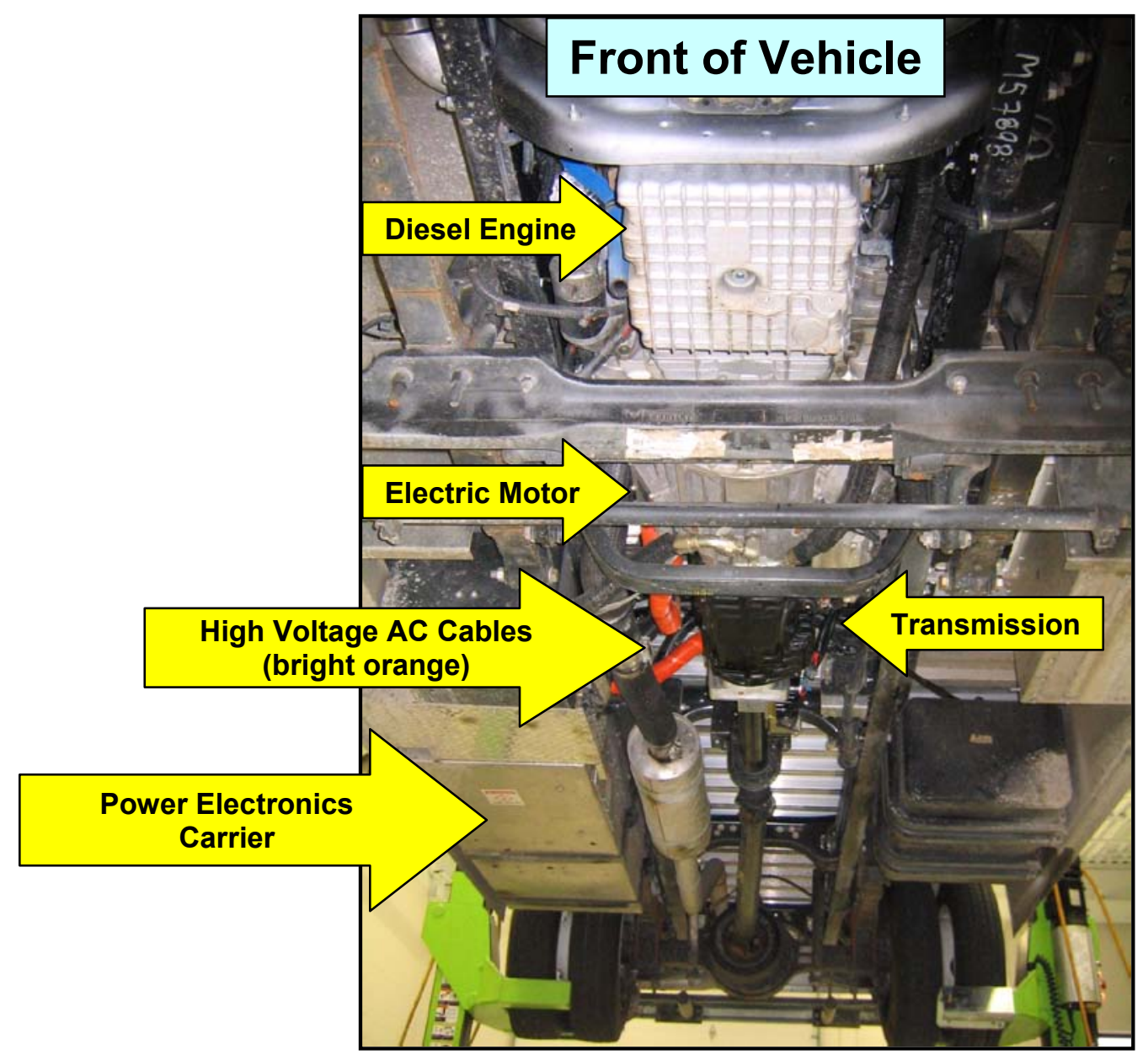

Figure 4. Eaton hybrid system components on UPS undercarriage

UPS has custom delivery vans built to the company's specifications. The P70 vehicles in this study are manufactured by Freightliner for UPS. Table 3 provides brief descriptions of the vehicle systems.

Table 3. Vehicle System Descriptions

\begin{tabular}{|l|l|l|}
\hline \multicolumn{1}{|c|}{ Van Specification } & \multicolumn{1}{c|}{ Hybrid Electric Vans } & \multicolumn{1}{c|}{ Diesel Vans } \\
\hline Van manufacturer & Freightliner Corp. & Freightliner Corp. \\
\hline Van model & P70H step van & P70D step van \\
\hline Van model year & 2007 & 2006 \\
\hline \multirow{2}{*}{ Engine manufacturer and model } & $\begin{array}{l}\text { Mercedes-Benz } \\
\text { MBE 904 4 cyl. } \\
\text { MY 2006 }\end{array}$ & $\begin{array}{l}\text { Mercedes-Benz } \\
\text { MBE 904 4 cyl. } \\
\text { MY 2006 }\end{array}$ \\
\hline Emissions equipment & No DPF & No DPF \\
\hline Retarder/regenerative braking & Regenerative braking & None \\
\hline Air conditioning type & None & None \\
\hline GVW & $15,200 \mathrm{lb}$ & $14,360 \mathrm{lb}$ \\
\hline
\end{tabular}

${ }^{a}$ DPF = diesel particle filter 


\section{Host Site Profile-UPS, Phoenix, Arizona}

The host site consisted of the two UPS Arizona facilities - Phoenix and Estrella. Estrella is an expansion facility located about five miles west of the main Phoenix facility, and it became necessary as the Phoenix facility outgrew its footprint. Figure 5 is a site map showing the locations of the two facilities in the greater Phoenix area. The vehicles used for this evaluation are six hybrids from the Phoenix facility and six standard diesels from the Estrella facility. It was not necessary to modify the Phoenix facility in any way to implement the hybrid vehicles into the fleet. Drivers were given training on the operation of the hybrids, but no restrictions or special accommodations were made for their use; however, UPS did assign them to urban routes rather than rural routes to make the best use of the hybrid drive train. Dispatch and maintenance practices are the same at both facilities. The Phoenix facility has on-site fueling, and the vehicles are fueled by drivers as needed, using an internal fuel card system. The Estrella facility does not have on-site fueling; drivers fuel the vehicles at public stations using a corporate fuel card. In both cases the drivers need to log their fueling events on their electronic tablets, and the records are uploaded to a central database.

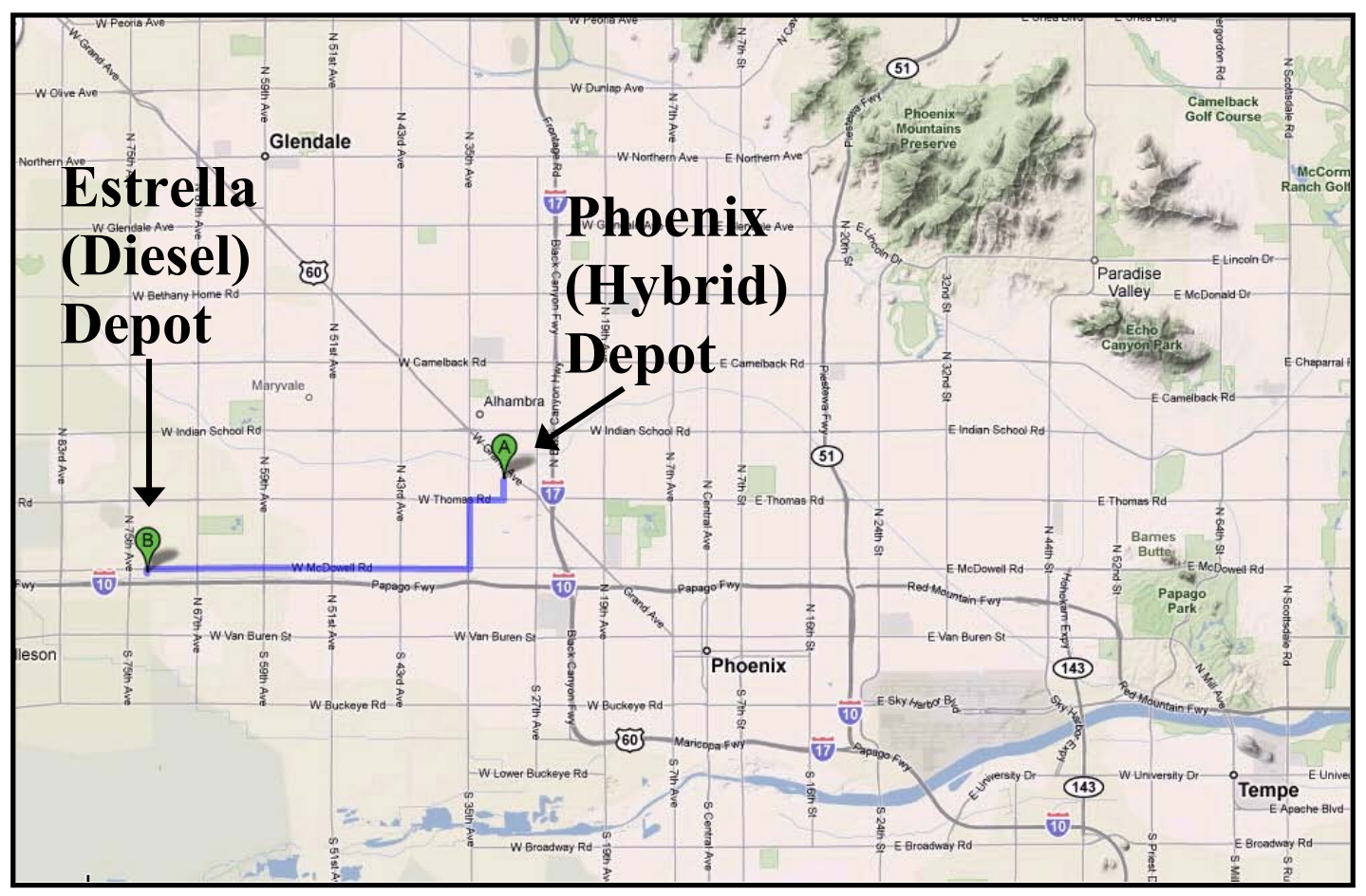

Figure 5. UPS Phoenix site map

\section{Evaluation Results}

\section{Van Use}

Figure 6 shows the average monthly miles driven per van for each van group with $\pm 95 \%$ confidence interval lines. An accident involving one hybrid van that affected mileage accumulation during August and September was not included in the figure. The width of the 95\% confidence interval gives some idea about how uncertain we are about the average. Van average usage did not change significantly during the first nine months of the evaluation period; the hybrids consistently were driven fewer miles throughout this period because of their shorter, 
more urban routes. In October and November, the hybrid group showed a dip in average usage and an increase in the $95 \%$ confidence interval due to calibration issues for three vans; the result was that these vehicles were not available for service for extended periods of time. Starting in October, the diesel group experienced an increase in miles per van resulting from UPS's consolidation of routes.

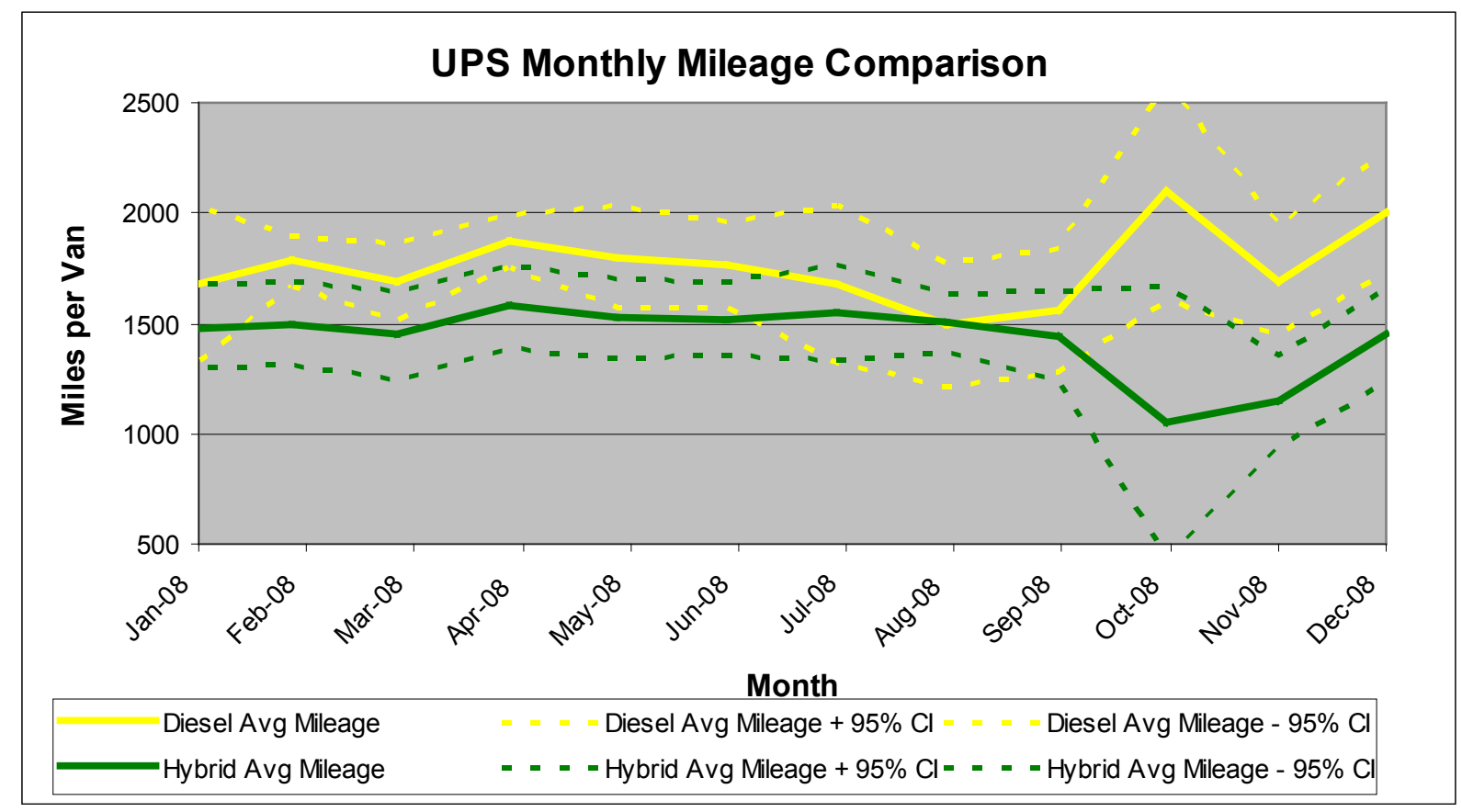

Figure 6. Hybrid and diesel monthly mileage per van

Table 4 presents the average monthly mileage per van during the evaluation period for the two groups of vans. The hybrids had a monthly mileage accumulation rate that is $20 \%$ less than that of the diesel vans (1,403 miles versus 1,758 miles). The average monthly rate was affected by downtime because four hybrid vehicles had a combined 7 months of operation impacted by extended downtime, as described above. With those 7 months of operation removed, the hybrids averaged 93 miles per month more, which was $15 \%$ less than that of the diesel group. This lower rate could also indicate a more urban duty cycle with lower speeds and more stops per mile. Half of this difference is explained by the $7.5 \%$ fewer average miles per day driven by the hybrids, as discussed in the Van Duty Cycle section of this report. 
Table 4. Average Van Miles Driven per Month by Study Group

\begin{tabular}{|l|r|r|r|r|r|}
\hline Van Number & $\begin{array}{c}\text { Start } \\
\text { Mileage }\end{array}$ & $\begin{array}{c}\text { End } \\
\text { Mileage }\end{array}$ & $\begin{array}{c}\text { Evaluated } \\
\text { Miles }\end{array}$ & $\begin{array}{c}\text { Miles per } \\
\text { Delivery } \\
\text { Day }\end{array}$ & $\begin{array}{c}\text { Miles per } \\
\text { Month }\end{array}$ \\
\hline 663982 & 59,305 & 77,899 & 18594 & 73.5 & 1,550 \\
\hline 665020 & 42,559 & 65,834 & 23275 & 93.1 & 1,940 \\
\hline 665044 & 30,682 & 51,526 & 20844 & 82.7 & 1,737 \\
\hline 665086 & 32,085 & 55,248 & 23163 & 91.9 & 1,930 \\
\hline 665087 & 43,875 & 65,412 & 21537 & 86.5 & 1,795 \\
\hline 665150 & 32,335 & 51,470 & 19135 & 75.9 & 1,595 \\
\hline Diesel Average & $\mathbf{4 0 , 1 4 0}$ & $\mathbf{6 1 , 2 3 2}$ & $\mathbf{2 1 , 0 9 1}$ & $\mathbf{8 4}$ & $\mathbf{1 , 7 5 8}$ \\
\hline Diesel Stdev & $\mathbf{1 0 , 9 7 6}$ & $\mathbf{1 0 , 4 0 9}$ & $\mathbf{1 , 9 6 9}$ & $\mathbf{8}$ & $\mathbf{1 6 4}$ \\
\hline 666131 & 11,813 & 24,210 & 12397 & 53.7 & 1,033 \\
\hline 666132 & 15,711 & 34,997 & 19286 & 82.1 & 1,607 \\
\hline 666133 & 15,598 & 34,834 & 19236 & 76.0 & 1,603 \\
\hline 666139 & 15,899 & 32,902 & 17003 & 76.2 & 1,417 \\
\hline 666142 & 14,212 & 30,224 & 16012 & 69.6 & 1,334 \\
\hline 666145 & 13,732 & 30,823 & 17091 & 68.6 & 1,424 \\
\hline HybridAverage & $\mathbf{1 4 , 4 9 4}$ & $\mathbf{3 1 , 3 3 2}$ & $\mathbf{1 6 , 8 3 8}$ & $\mathbf{7 1}$ & $\mathbf{1 , 4 0 3}$ \\
\hline Hybrid Stdev & $\mathbf{1 , 5 8 3}$ & $\mathbf{4 , 0 0 9}$ & $\mathbf{2 , 5 3 9}$ & $\mathbf{1 0}$ & $\mathbf{2 1 2}$ \\
\hline Difference & $\mathbf{2 5 , 6 4 6}$ & $\mathbf{2 9 , 9 0 0}$ & $\mathbf{4 , 2 5 4}$ & $\mathbf{1 3}$ & $\mathbf{3 5 4}$ \\
\hline \% Difference & $\mathbf{6 4 \%}$ & $\mathbf{4 9} \%$ & $\mathbf{2 0 \%}$ & $\mathbf{1 5 \%}$ & $\mathbf{2 0 \%}$ \\
\hline & & & & & \\
\hline
\end{tabular}

\section{Van Duty Cycle}

GPS data loggers were installed in two vans from each study group to obtain detailed information on the routes they were assigned to. Data were collected for one week of operation, providing 10 days of "typical" operation for each vehicle group. The data are not representative of the entire UPS fleet but only of the P70 vehicles operating out of these two depots. Figure 7 shows a GPS visualization of the routes of the four logged vans. The red and orange traces each show one day of the diesel van's operations out of the Estrella depot. The blue and purple traces each show one day of the hybrid van's operations out of the Phoenix depot. The exact routes vary daily, but the depictions shown are typical of a day of operation for that van, as captured by the GPS loggers. 


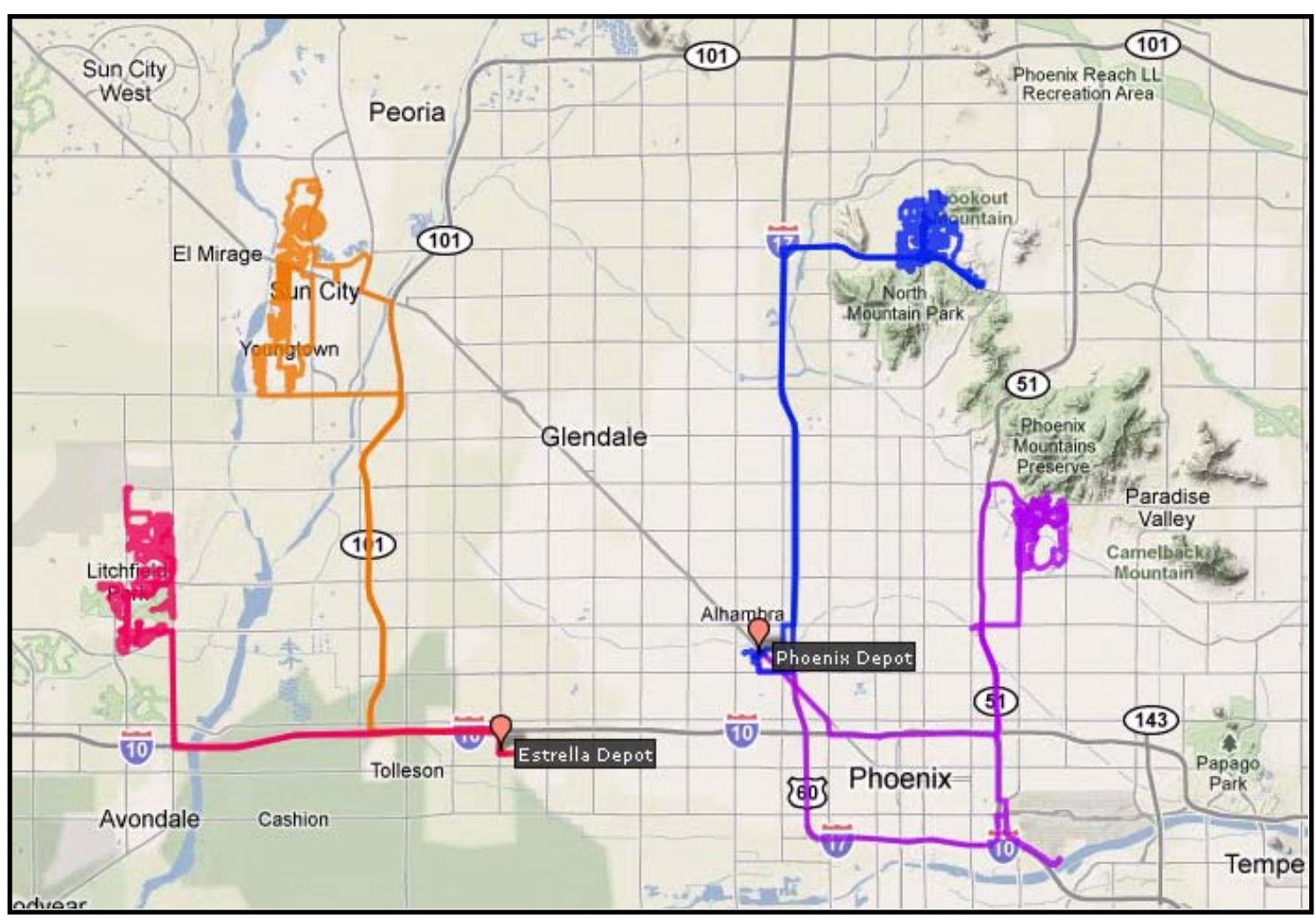

Figure 7. Hybrid and diesel route visualization

Figure 8 shows the average time (as a percentage) that vans with GPS loggers spent at different vehicle speeds. The hybrids spent more time idling and operating at slower speeds than the diesels did, and the diesels spent slightly more time operating at higher speeds.

- The hybrid vans spent $13 \%$ of their time at zero speed, about twice the idle time spent by the diesels $(6.1 \%)$.

- The hybrid vans spent $20 \%$ of their time in the 0 to $10 \mathrm{mph}$ range, $31 \%$ more than the diesels did (15\%).

- The hybrid vans spent $18 \%$ of their time in the $20-35 \mathrm{mph}$ range, $32 \%$ less time than the diesels spent there (26\%).

- The hybrids spent $7.6 \%$ of their time in the $50-65 \mathrm{mph}$ range, twice as much as the diesels did (3.7\%).

- The diesels spent significantly more time above $65 \mathrm{mph}$ (5\% vs. $1 \%$ for the hybrids). This was because the hybrids are speed-limited while the diesel vans are not.

The greater time spent by the hybrids at slower speeds indicates a more urban duty cycle; had the diesel group driven the same exact duty cycle, they likely would have had lower fuel economy as a result. Both groups spent about $70 \%$ of their non-idle driving time at speeds less than $35 \mathrm{mph}$, indicating that both groups were on city/residential delivery routes. The higher average highway speed could also negatively impact the fuel economy of the diesel group as a result of higher 
aerodynamic drag. Both groups spent about $8.5 \%$ of their driving time at speeds above $50 \mathrm{mph}$, indicating they had similar distances to travel from depot to delivery zone.

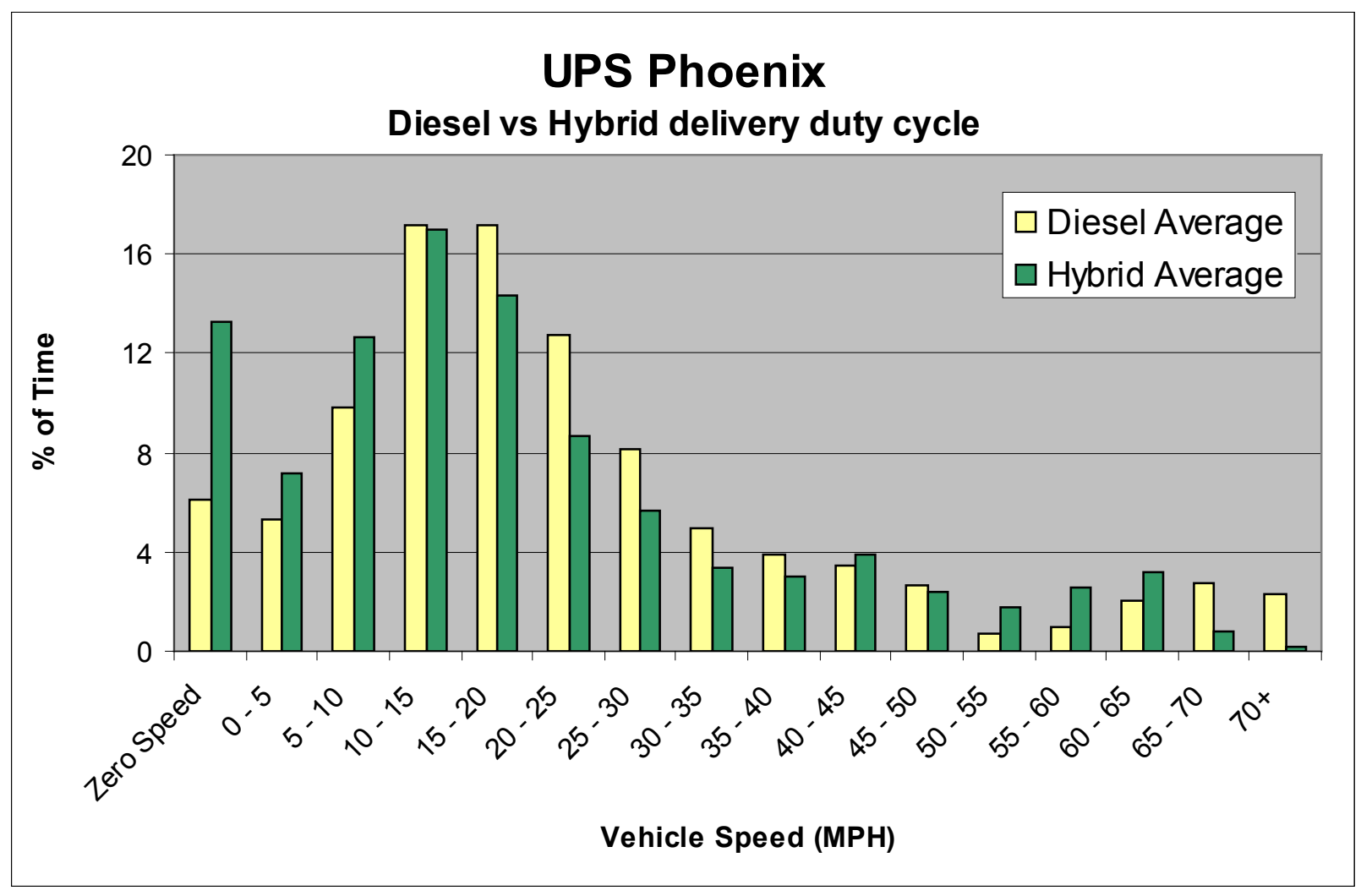

Figure 8. Hybrid and diesel duty cycle breakdown

Table 5 presents other duty-cycle statistics gathered from the GPS data logging.

- The hybrids' average driving speed of 22.3 mph was $7 \%$ lower than the diesels' 24.1 mph.

- $\quad$ The hybrids averaged 94 stops per day, 90\% more than the diesels' 49 stops.

- $\quad$ The hybrids averaged 1.4 stops per mile, twice as many stops per mile as the diesels' 0.7 .

- $\quad$ The hybrids had 16.9 acceleration events per mile, $22 \%$ more than the diesels' 13.8 .

- The hybrids had 15.8 deceleration events per mile, 19\% more than the diesels' 13.3 .

These statistics indicate that the hybrids were operating in a more dense urban delivery zone than the diesels were. The lower speeds and more stops per mile are in line both with the hybrids' greater percent of time spent at speeds lower than $10 \mathrm{mph}$ and the fewer miles driven per month. The $7.5 \%$ fewer average miles per day explains part of the $15 \%$ fewer miles per month mentioned in the Van Use section. 
Table 5. Drive Cycle Statistics from Vans with GPS Loggers from Each Study Group

\begin{tabular}{|l|r|r|r|r|}
\hline Cycle Statistics & $\begin{array}{c}\text { Diesel } \\
\text { Average }\end{array}$ & $\begin{array}{c}\text { Hybrid } \\
\text { Average }\end{array}$ & $\begin{array}{c}\text { Difference } \\
\text { (Diesel - } \\
\text { Hybrid) }\end{array}$ & \% Difference \\
\hline Distance traveled (miles) & 73.7 & 68.2 & 5.5 & $-7.5 \%$ \\
\hline Average speed over cycle (mph) & 22.6 & 19.4 & 3.2 & $-14.3 \%$ \\
\hline Average driving speed (mph) & 24.1 & 22.3 & 1.8 & $-7.3 \%$ \\
\hline Maximum speed (mph) & 74.0 & 69.2 & 4.8 & $-6.5 \%$ \\
\hline Time at idle (s) & 732 & 1725 & -993 & $136 \%$ \\
\hline Maximum acceleration (ft/s $\left.{ }^{2}\right)$ & 12.8 & 10.0 & 2.8 & $-21.8 \%$ \\
\hline Maximum deceleration (ft/s ${ }^{2}$ ) & -10.0 & -10.9 & 0.9 & $9.1 \%$ \\
\hline Acceleration (\% of total cycle) & 44.1 & 40.0 & 4.0 & $-9.2 \%$ \\
\hline Deceleration (\% of total cycle) & 40.8 & 35.7 & 5.1 & $-12.4 \%$ \\
\hline Average acceleration (ft/s $\left.{ }^{2}\right)$ & 1.9 & 2.0 & -0.1 & $3.8 \%$ \\
\hline Average deceleration (ft/s $\left.{ }^{2}\right)$ & -2.0 & -2.2 & 0.2 & $7.5 \%$ \\
\hline Number of acceleration events & 1018.3 & 1150.2 & -131.9 & $13.0 \%$ \\
\hline $\begin{array}{l}\text { Number of acceleration events per } \\
\text { mile }\end{array}$ & 13.8 & 16.9 & -3.1 & $22.3 \%$ \\
\hline Number of deceleration events & 983.1 & 1077.9 & -94.8 & $9.6 \%$ \\
\hline $\begin{array}{l}\text { Number of deceleration events per } \\
\text { mile }\end{array}$ & 13.3 & 15.8 & -2.5 & $18.6 \%$ \\
\hline Number of stops & 49.2 & 93.9 & -44.7 & $90.9 \%$ \\
\hline Average duration of stop (s) & 14.5 & 18.4 & -3.9 & $27.3 \%$ \\
\hline Number of stops per mile & 0.7 & 1.4 & -0.7 & $105.9 \%$ \\
\hline
\end{tabular}

\section{Fuel Economy}

UPS fuels its hybrids and diesels with standard ultra-low-sulfur diesel (ULSD), which has a sulfur content of less than 30 parts per million (ppm). From June through September, three diesel vans experienced spikes in their monthly fuel economy:

- One van had 1 month of high fuel economy results

- One van had 2 months of high fuel economy results

- One van had 3 months of very high fuel economy results.

UPS confirmed that drivers failed to log fueling events during this period of time. In one case, an impossible number of miles were accumulated without a recorded fueling event. The six suspect diesel-group vehicle months of fuel economy data have been removed from the total of 72 diesel-group vehicle months of results presented in this report. As such, miles used are different for the calculation of diesel-group fuel economy than those reported in other sections of the report.

Table 6 shows the fuel consumption and economy data for each van in each study group. The hybrid vans consumed 7,714 gallons of fuel over 101,025 miles for the 12-month period, resulting in an average fuel economy for the hybrid vans of $13.1 \mathrm{mpg}$, which was $28.9 \%$ greater than that of the diesel van group's $10.2 \mathrm{mpg}(\mathrm{P}$ value $=0.0002)$. 
Table 6. Hybrid and Diesel Van Fuel Use and Economy

\begin{tabular}{|ccccc|}
\hline \multicolumn{4}{c}{ Hybrid Vehicles } \\
Van & Miles & $\begin{array}{c}\text { Gallons } \\
\text { Consumed }\end{array}$ & $\begin{array}{c}\text { Miles per } \\
\text { Gallon }\end{array}$ \\
666131 & 12,397 & 989 & 12.5 \\
666132 & 19,286 & 1,395 & 13.8 \\
666133 & 19,236 & 1,455 & 13.2 \\
666139 & 17,003 & 1,357 & 12.5 \\
666142 & 16,012 & 1,281 & 12.5 \\
666145 & 17,091 & 1,237 & 13.8 \\
\hline Hybrid Total & 101,025 & 7,714 & 13.1 \\
\hline \multicolumn{5}{|c}{ Diesel Vehicles } \\
Van & Fuel Economy & Fuel Economy & Miles per \\
\hline 663982 & Miles & Gallons & Gallon \\
665020 & 15,590 & 1,463 & 10.7 \\
665044 & 23,275 & 2,203 & 10.6 \\
665086 & 19,052 & 1,819 & 10.5 \\
665087 & 20,204 & 2,322 & 8.7 \\
665150 & 21,537 & 2,181 & 9.9 \\
\hline Diesel Total & 19,135 & 1,706 & 11.2 \\
\hline
\end{tabular}

Figure 9 shows the monthly miles per gallon for each van group and cumulative miles per gallon for each van group. In this figure, the group is considered as a whole, and monthly miles per gallon are calculated by considering the sum of the miles and sum of the gallons for the group each month. This figure weights all vehicle miles equally and relates directly to the fleet's actual fuel consumption.

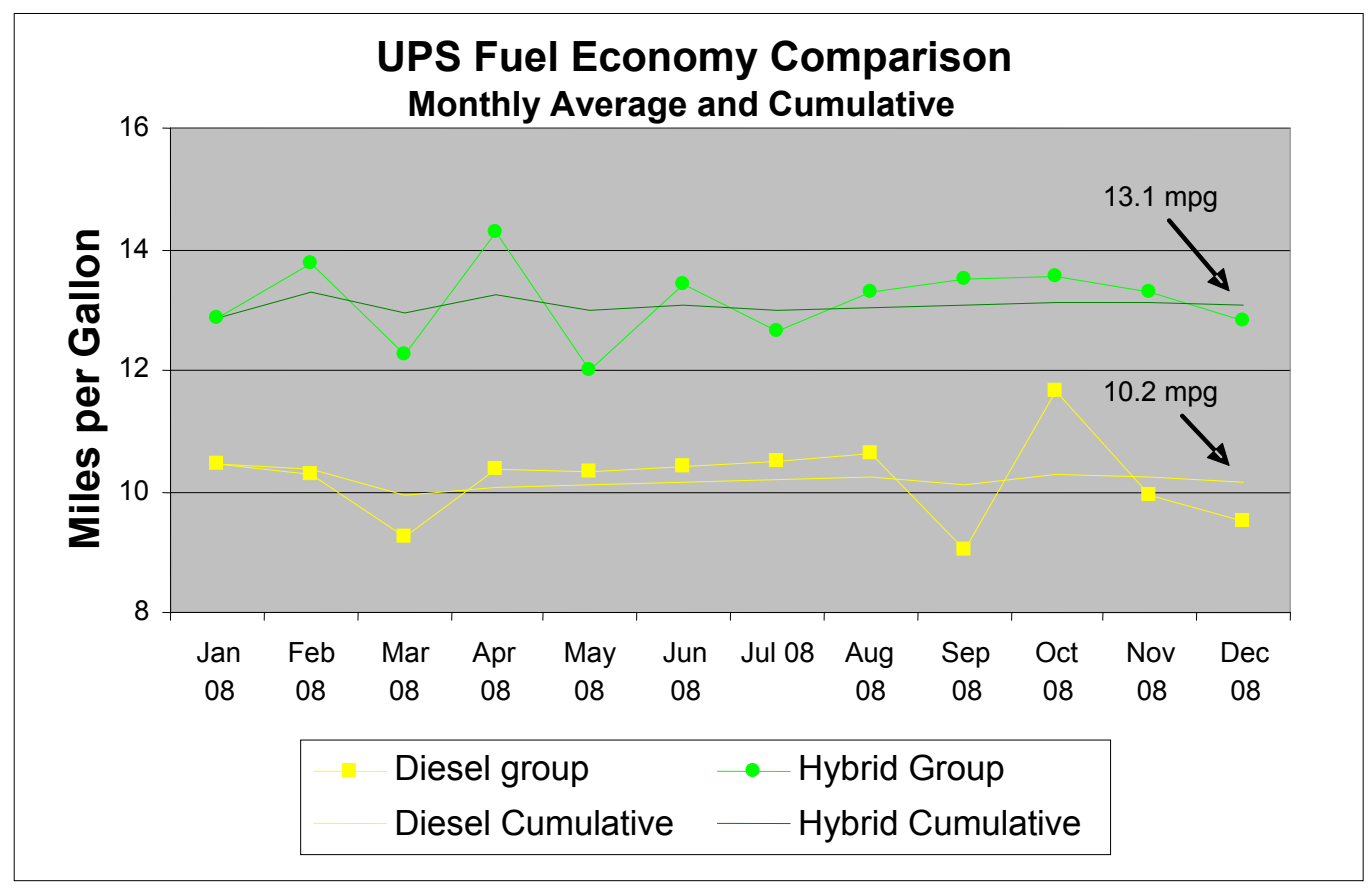

Figure 9. Average monthly and cumulative fuel economy 
Figure 10 shows the average monthly miles per gallon for each group of vans with $\pm 95 \%$ confidence interval lines. This figure considers each group as six individual vehicles and averages their monthly miles per gallon results. This figure weights each vehicle equally and better takes into account the effect of different duty cycles and miles per day on fuel economy. With a small sample size, one outlier can offset the average significantly. The width of the $95 \%$ confidence interval gives some idea about how uncertain we are about the average. By considering each vehicle as an individual and calculating a $95 \%$ confidence interval, it is possible to understand the consistency of the population's fuel economy and gain a better understanding of how a larger population of vehicles would behave. The average miles per gallon results can be different from those obtained when considering the group as a whole, as in Figure 9 , and in this study, both groups have $1 \%-2 \%$ higher monthly miles per gallon results with this calculation, with few exceptions.

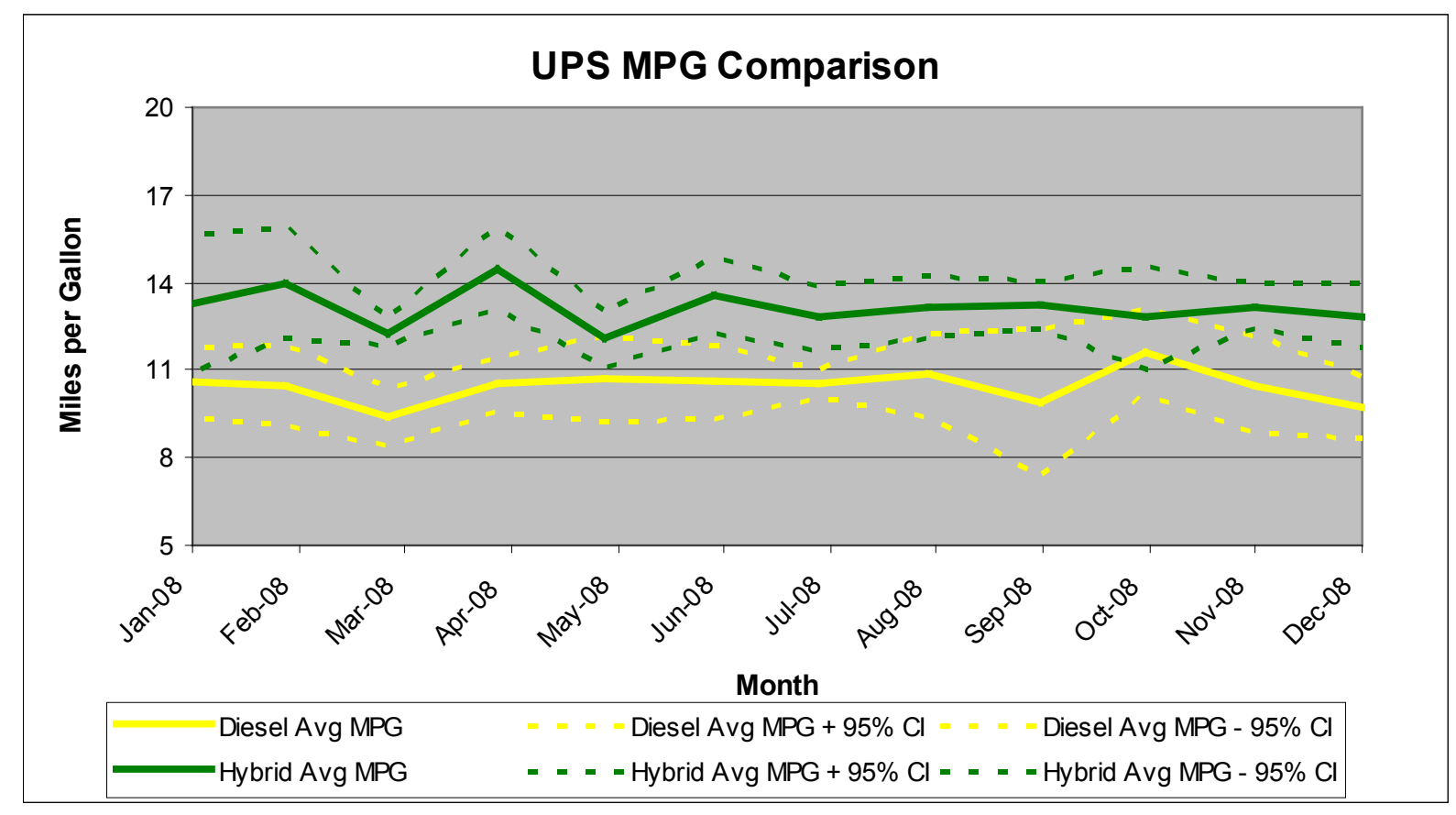

Figure 10. Average monthly fuel economy

\section{Maintenance Cost Analysis}

This evaluation focuses on van operations spanning 12 of the first 18 months of operation for the hybrid vans. This snapshot does not yield enough capital and operating cost data to provide a complete understanding of the full life-cycle cost of the hybrid vans, however. Understanding costs requires an examination of the purchase cost of the vans plus warranty and operation costs. Longer term maintenance activities, such as engine rebuilds or replacements and battery replacements, also must be considered. Finally, it is critical that areas in which cost savings can be achieved (e.g., in brake repair) be examined. The intent of this evaluation, however, is to capture accurate actual capital and known operations costs associated with the hybrid and diesel vehicles for the selected period. This analysis is not predictive of maintenance costs assumed by UPS beyond the warranty period. The exact components and warranty periods - as negotiated by UPS, Eaton, and Freightliner - are contractual and confidential. 
The hybrid and diesel vans all are new enough that much of the maintenance is completed under warranty. All maintenance for the Eaton hybrid drive was done by Eaton mechanics. These maintenance costs are not included in the maintenance-cost analysis in this section. Not accounting for warranty repairs in the evaluation of total maintenance cost does offer an incomplete picture of total maintenance cost. Even without warranty costs, however, this analysis reflects the actual cost to UPS during the period selected.

Maintenance costs were collected in the same manner for each study group. All work orders and parts information available were collected for the study vans, and the maintenance practices are the same for both diesel and hybrid study groups. The maintenance analysis discussions include only the maintenance data that were gathered during the evaluation period on the study group vans.

\section{Maintenance Costs}

This cost category includes the costs for parts and for labor, at $\$ 50$ per hour; it does not include warranty costs. All costs related to an accident on a hybrid vehicle have been removed from this section as they do not represent the vehicle and powertrain comparison of interest. Cost per mile is calculated as follows.

$$
\text { Cost per mile }=((\text { labor hours } * 50)+\text { parts cost }) / \text { mileage } .
$$

The labor rate has been set artificially at a constant rate of $\$ 50$ per hour so other analysts can change this rate to one more similar to their own situations. This rate does not directly reflect UPS's current hourly mechanic rate.

Table 7 shows total and propulsion-related maintenance costs for the two study groups. The propulsion-related vehicle systems include the engine; transmission; electric propulsion; exhaust; fuel; and nonlighting electrical, which includes general electrical, charging, cranking, and ignition. The propulsion-related maintenance cost per mile of $\$ 0.034$ for the hybrid vans was $5 \%$ less than the $\$ 0.036$ for the diesel vans. The total maintenance cost per mile of $\$ 0.140$ for the hybrid vans was $8 \%$ less than the $\$ 0.152$ for the diesel vans.

Table 7. Hybrid and Diesel Van Total and Propulsion Maintenance Costs

\begin{tabular}{|l|c|c|c|c|c|}
\hline Study Group & Miles & Parts Cost & $\begin{array}{c}\text { Labor } \\
\text { Hours }\end{array}$ & $\begin{array}{c}\text { Maintenance } \\
\text { Cost }\end{array}$ & $\begin{array}{c}\text { Cost per } \\
\text { Mile (\$/mile) }\end{array}$ \\
\hline Hybrid total & 101,025 & $\$ 3,985$ & 203.3 & $\$ 14,148$ & $\$ 0.140$ \\
\hline Hybrid propulsion-related & 101,025 & $\$ 38$ & 69.0 & $\$ 3,485$ & $\$ 0.034$ \\
\hline Diesel total & 126,548 & $\$ 7,122$ & 242.8 & $\$ 19,260$ & $\$ 0.152$ \\
\hline Diesel propulsion-related & 126,548 & $\$ 1,545$ & 61.0 & $\$ 4,594$ & $\$ 0.036$ \\
\hline
\end{tabular}

Included in the "total" maintenance cost data are tire replacements, which are a large part of the vehicle operating costs and are responsible for spikes in monthly total maintenance costs. Cumulative tire expenses are on the same level as cumulative propulsion-related costs for either drive train ( $\$ 0.032 / \mathrm{mile}$ to $\$ 0.037 / \mathrm{mile})$. Figure 11 shows total monthly and cumulative maintenance costs for the two study groups. Tire costs are responsible for most of the spike in March (\$0.08/mile) for the hybrid group. A group of tire changes during the month of September (\$0.16/mile) is responsible for the spike during that month. While both study groups have similar tire replacement costs over the course of the year $(\$ 3,688$ for hybrids vs. $\$ 4,041$ for diesels), the 
hybrids seem to experience them in large groups that create spikes, while for the diesel group, the replacements are spread evenly over the course of the year. This is likely because the hybrids were all put in service during the same month in 2007, while the diesels were put in service over about 9 months in that same year. This resulted in a much higher standard deviation in evaluation start mileages and, as such, a wider range of tire wear-out events. The hybrids had a lower average evaluation start mileage; the range of start mileages was one-seventh that of the diesel group, as discussed in the Van Use section.

Table 8 shows a breakdown by individual van of the total cost per mile. Total maintenance cost per mile between the diesel and hybrid groups had no statistical significance ( $\mathrm{P}$ value $=0.82$ ). Propulsion maintenance cost per mile showed no statistically significant difference between the diesel and hybrid groups (P value $=0.95)$. Fuel cost per mile dominated the total cost per mile for both groups, and the fuel cost per mile was $22 \%$ less for the hybrid group ( $\mathrm{P}$ value $=0.0008$ ). As such, total cost per mile was 18\% less for the hybrid group ( $\mathrm{P}$ value $=0.0134)$. The 2008 average price for diesel was $\$ 3.80 /$ gallon, and this figure was used to calculate fuel cost per mile.

Table 8. Hybrid and Diesel Van Total Cost per Mile

\begin{tabular}{|c|c|c|c|c|c|c|c|c|c|}
\hline \multicolumn{10}{|c|}{ Total Cost per Mile Comparison } \\
\hline Car & PWRTRN & \multirow{2}{*}{\begin{tabular}{|l}
$\begin{array}{l}\text { Mileage } \\
\text { Total }\end{array}$ \\
18,594
\end{tabular}} & $\begin{array}{l}\text { Non-Prop Mnt } \\
\text { (\$/mile) }\end{array}$ & \multicolumn{2}{|c|}{$\begin{array}{l}\text { Prop Maint } \\
\text { (\$/mile) }\end{array}$} & \multicolumn{2}{|c|}{$\begin{array}{l}\text { Fuel Cost } \\
\text { (\$/mile) }\end{array}$} & \multicolumn{2}{|c|}{$\begin{array}{l}\text { Total Cost } \\
\text { (\$/mile) }\end{array}$} \\
\hline 663982 & Diesel & & $\$ 0.142$ & $\$$ & 0.077 & $\$$ & 0.357 & $\$$ & 0.576 \\
\hline 665020 & Diesel & 23,275 & $\$ 0.077$ & $\$$ & 0.032 & $\$$ & 0.360 & $\$$ & 0.468 \\
\hline 665044 & Diesel & 20,844 & $\$ 0.119$ & $\$$ & 0.038 & $\$$ & 0.363 & $1 \$$ & 0.519 \\
\hline 665086 & Diesel & 23,163 & $\$ 0.141$ & $\$$ & 0.023 & $\$$ & 0.437 & $\$$ & 0.601 \\
\hline 665087 & Diesel & 21,537 & $\$ 0.140$ & $\$$ & 0.017 & $\$$ & 0.385 & $\$$ & 0.542 \\
\hline 665150 & Diesel & 19,135 & $\$ 0.077$ & $\$$ & 0.038 & $\$$ & 0.339 & $\$$ & 0.454 \\
\hline Total & Diesel & 126,548 & $\$ 0.116$ & $\$$ & 0.036 & $\$$ & 0.374 & $\$$ & 0.526 \\
\hline 666131 & Hybrid Diesel & 12,397 & $\$ 0.112$ & $\$$ & 0.061 & $\$$ & 0.303 & $\$$ & 0.476 \\
\hline 666132 & Hybrid Diesel & 19,286 & $\$ 0.064$ & $\$$ & 0.020 & $\$$ & 0.275 & $\$$ & 0.358 \\
\hline 666133 & Hybrid Diesel & 19,236 & $\$ 0.087$ & $\$$ & 0.020 & $\$$ & 0.287 & $\$$ & 0.394 \\
\hline 666139 & Hybrid Diesel & 17,003 & $\$ 0.089$ & $\$$ & 0.024 & $\$$ & 0.303 & $\$$ & 0.416 \\
\hline 666142 & Hybrid Diesel & 16,012 & $\$ 0.145$ & $\$$ & 0.067 & $\$$ & 0.304 & $\$$ & 0.515 \\
\hline 666145 & Hybrid Diesel & 17,091 & $\$ 0.149$ & $\$$ & 0.029 & $\$$ & 0.275 & $\$$ & 0.453 \\
\hline Total & Hybrid Diese & 101,025 & $\$ 0.106$ & $\$$ & 0.034 & $\$$ & 0.290 & $\$$ & 0.430 \\
\hline
\end{tabular}




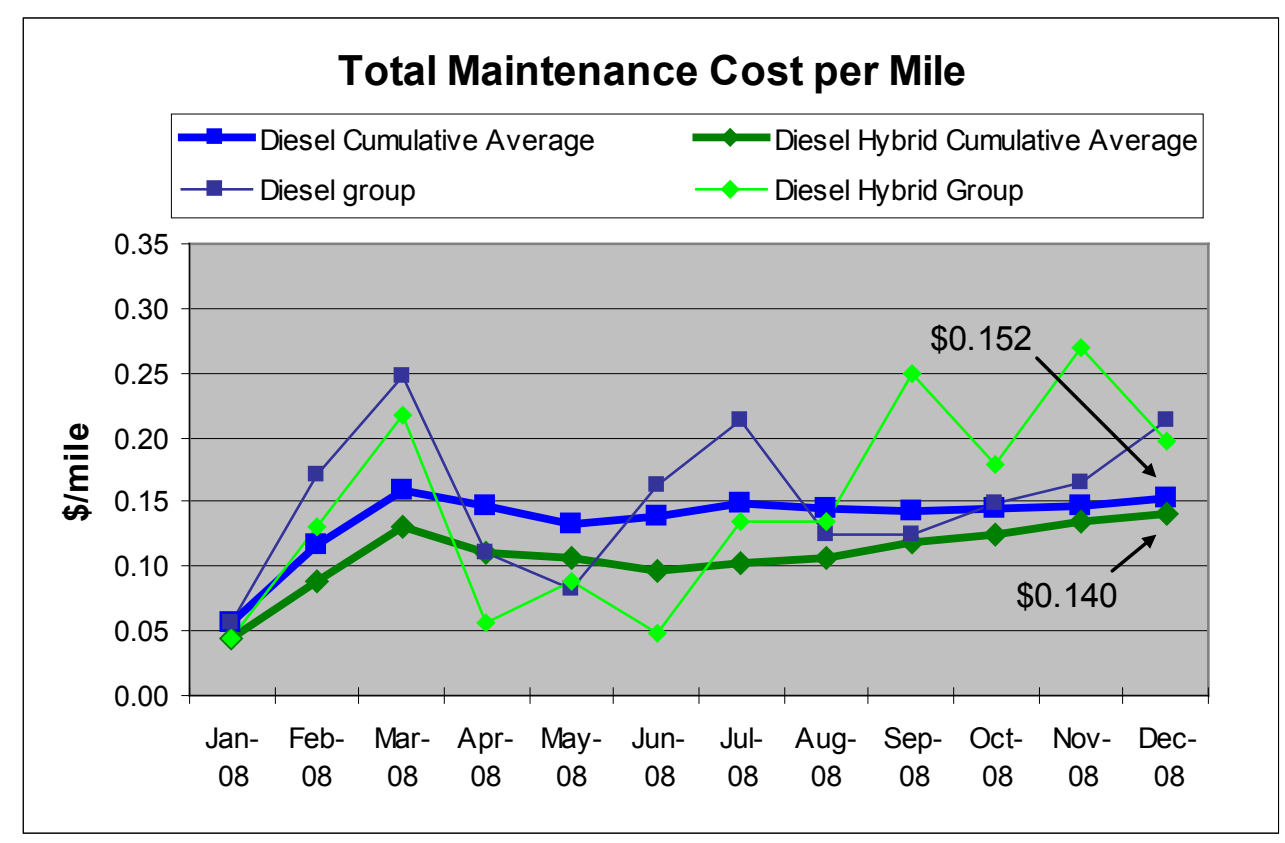

Figure 11. Total maintenance cost per mile

Figure 12 shows monthly and cumulative propulsion-related maintenance costs for the two study groups. The hybrid spike during October and November is due to Eaton recalibration activities and is responsible for raising the hybrid cumulative propulsion-related maintenance cost per mile to parity with that of the diesel group. Three of the hybrid units were experiencing faults related to the calibration of a prototype parking pawl in use on these vans. While Eaton covered the costs for materials, UPS technicians spent time troubleshooting and working with Eaton, and these hours generated the spike in propulsion maintenance cost per mile.



Figure 12. Propulsion maintenance cost per mile 
Figures 13 and 14 show a breakdown of total and propulsion-related maintenance costs per mile for the diesel and hybrid study groups, respectively. Note the similar percentage breakdowns for each category, which indicates that the hybrid drivetrain is not driving maintenance costs any more than the standard conventional drivetrain. Also note that for both study groups, the complete propulsion system costs an amount similar to the tire-related costs for the group. Propulsion system and tire-related costs were $19 \%$ and $17 \%$, respectively, for the diesel group and $20 \%$ and $21 \%$, respectively, for the hybrid group.

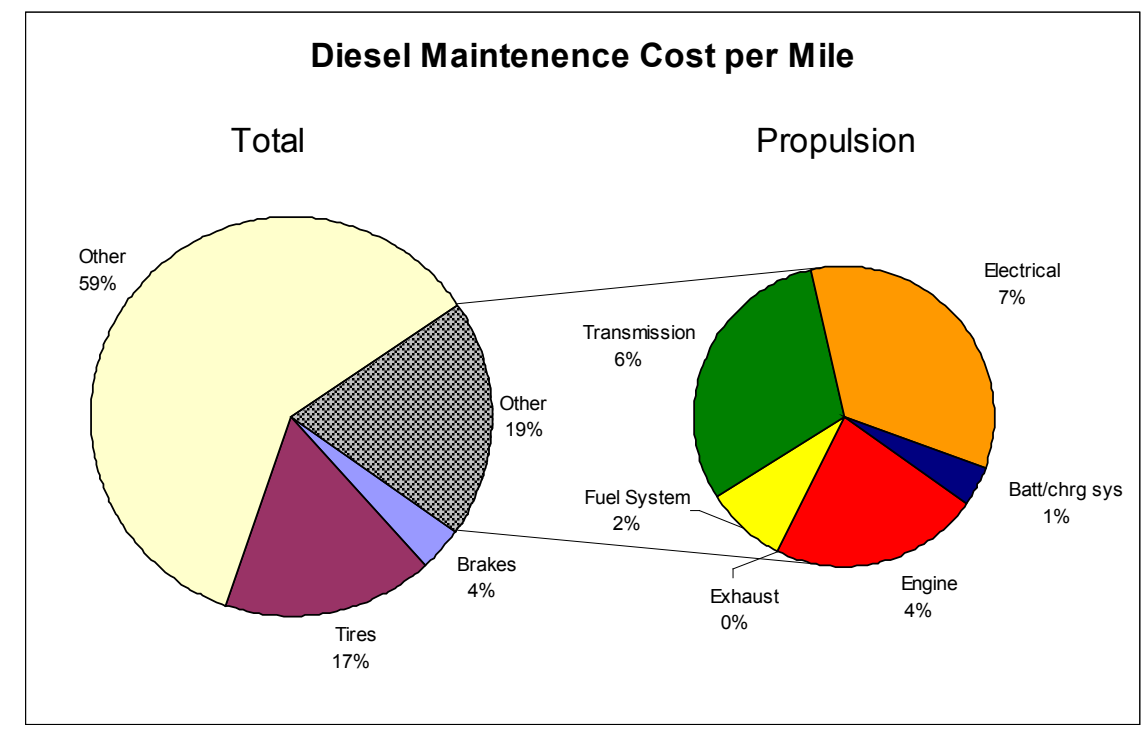

Figure 13. Propulsion maintenance cost per mile (diesels)

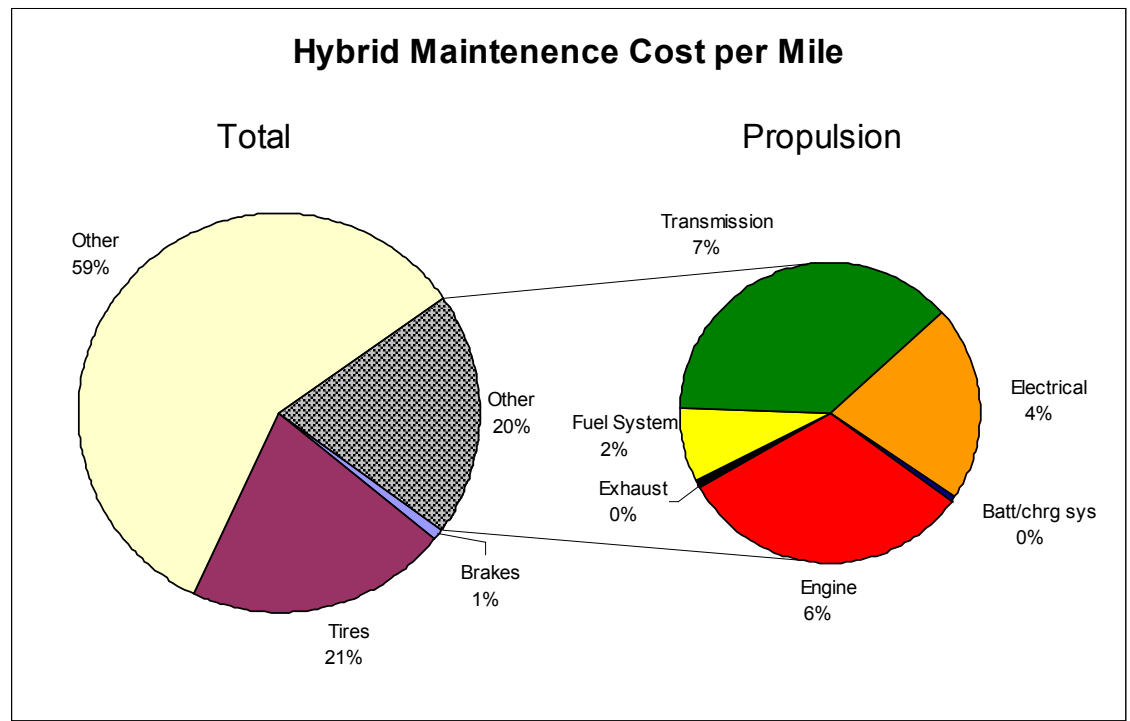

Figure 14. Propulsion maintenance cost per mile (hybrids)

\section{Reliability}

UPS records instances in which a vehicle is not available to load in the morning, as scheduled. Scheduled maintenance events of any kind do not get recorded in this way. During this 12-month evaluation, there were 253 operational days available for deliveries. That is a total of 1,518 days for each study group of six vans. Both groups had a comparable number of missed operational 
days during the first 6 months of the evaluation. In August one of the hybrid vehicles was involved in an accident, which caused it to miss 29 operational days during August and September. A combined 55 operational days were missed during October and November while Eaton was troubleshooting faults related to a prototype parking pawl on three of the hybrid units. The diesel study group missed a total of 10 operational days during the 12-month study period, while the hybrid group missed 68 operational days for the reasons mentioned above (excluding the accident). Table 9 breaks down the monthly and cumulative uptime percent for each group. Figure 15 shows the monthly and cumulative uptime for each group as a percentage of the total available delivery days. The 29 days missed because of an accident are not included in Table 9 or Figure 15 because that event was outside normal van and powertrain operations.

Table 9. Hybrid and Diesel Van Cumulative Missed Operating Days

\begin{tabular}{|c|c|c|c|c|c|c|c|c|c|c|c|c|}
\hline & $\underline{\text { Jan }}$ & Feb & Mar & Apr & May & Jun & Jul & Aug & Sep & Oct & Nov & Dec \\
\hline Diesel Monthly \% uptime & $100 \%$ & $99.2 \%$ & $97.6 \%$ & $100 \%$ & $100 \%$ & $100 \%$ & $96.2 \%$ & $100 \%$ & $100 \%$ & $99.3 \%$ & $100 \%$ & $100 \%$ \\
\hline Hybrid Monthly \% uptime & $100 \%$ & $100 \%$ & $97.6 \%$ & $100 \%$ & $100 \%$ & $100 \%$ & $100 \%$ & $98.4 \%$ & $100 \%$ & $65.9 \%$ & $85.2 \%$ & $100 \%$ \\
\hline Diesel Cumulative $\%$ uptime & $100 \%$ & $99.6 \%$ & $99.0 \%$ & $99.2 \%$ & $99.4 \%$ & $99.5 \%$ & $99.0 \%$ & $99.1 \%$ & $99.2 \%$ & $99.2 \%$ & $99.3 \%$ & $99.3 \%$ \\
\hline Hybrid Cumulative $\%$ uptime & $100 \%$ & $100 \%$ & $99.2 \%$ & $99.4 \%$ & $99.5 \%$ & $99.6 \%$ & $99.7 \%$ & $99.5 \%$ & $99.6 \%$ & $96.0 \%$ & $95.1 \%$ & $95.5 \%$ \\
\hline
\end{tabular}

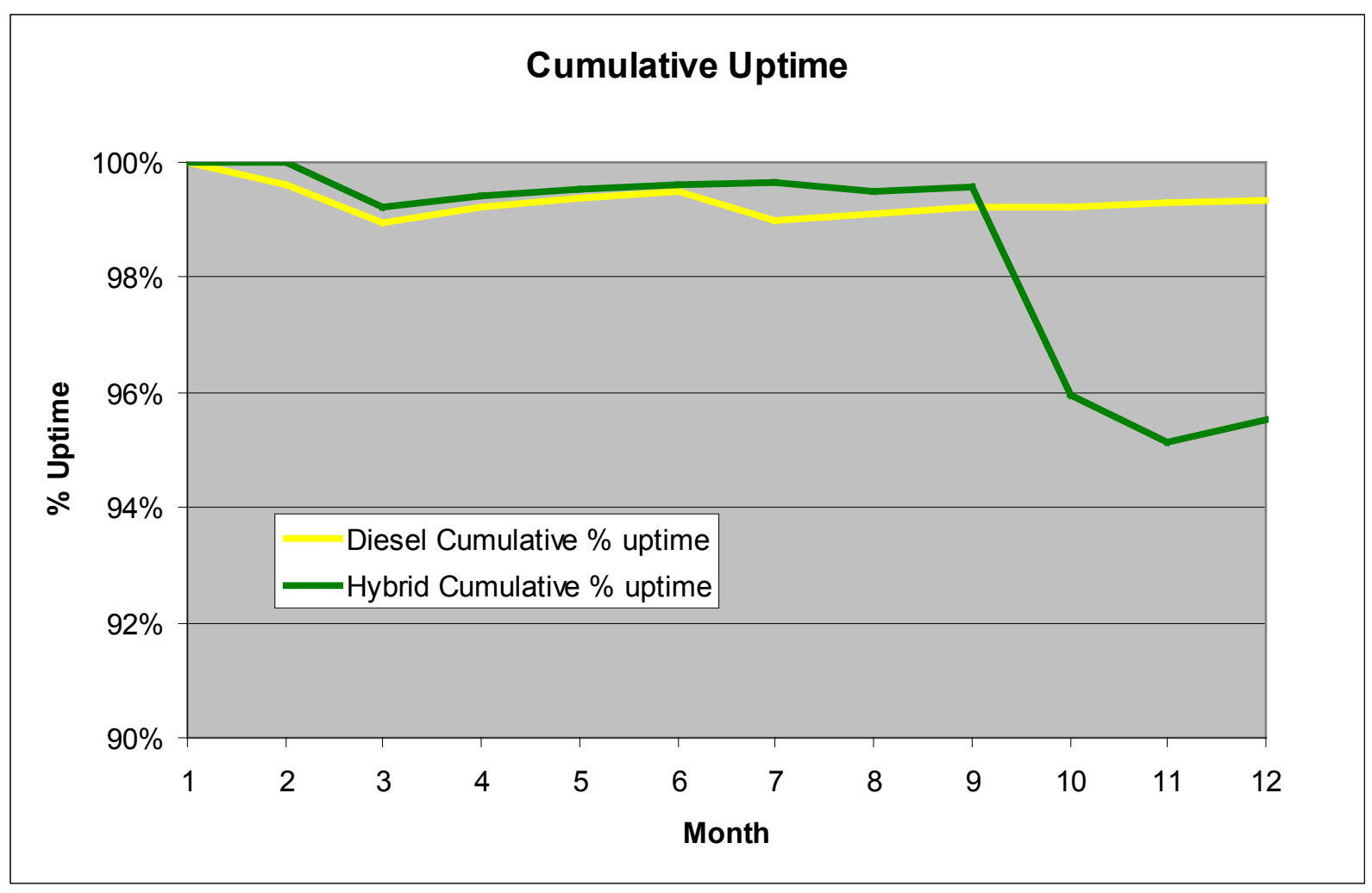

Figure 15. Cumulative uptime

\section{Batteries}

The Eaton system uses lithium ion batteries supplied by Hitachi for energy storage. They have a capacity of $1.8 \mathrm{kWh}$ and operate at a nominal voltage of 340 VDC. These batteries were not available to NREL during the evaluation period for detailed evaluation. The batteries are included in the power electronics carrier (PEC). Eaton's records indicate one PEC was replaced because of water intrusion during an atypical monsoon flood event. UPS records indicate 
preventive efforts to seal the PEC air filter on the hybrids, and these costs are captured as part of the maintenance cost analysis under the "electrical" heading. No record of a battery failure or a cell failure exists. The service life of the battery is estimated by Eaton at 7 years.

\section{Laboratory Fuel Economy and Emissions Testing}

This work comprises chassis dynamometer testing of two UPS delivery vehicles. The remainder of this document includes the test plan and results from vehicle testing performed at NREL's ReFUEL Research Laboratory. The ReFUEL laboratory description, experimental setup, and test procedures can be found in the appendix.

\section{Test Plan}

Tests were performed on one 2007 hybrid electric Workhorse P100 delivery van and one conventional 2007 Workhorse P100 delivery van during May and June 2007 to determine emissions and fuel economy benefits of the hybrid electric powertrain being evaluated at UPS. The tests were conducted over three driving cycles: the Combined International Local and Commuter Cycle (CILCC), the West Virginia University City (WVU City) cycle, and the Central Business District (CBD) cycle. Vehicle exhaust emissions and fuel consumption were measured for repeated test conditions. The speed/time traces of each cycle are shown in Figures 16,17 , and 18 .

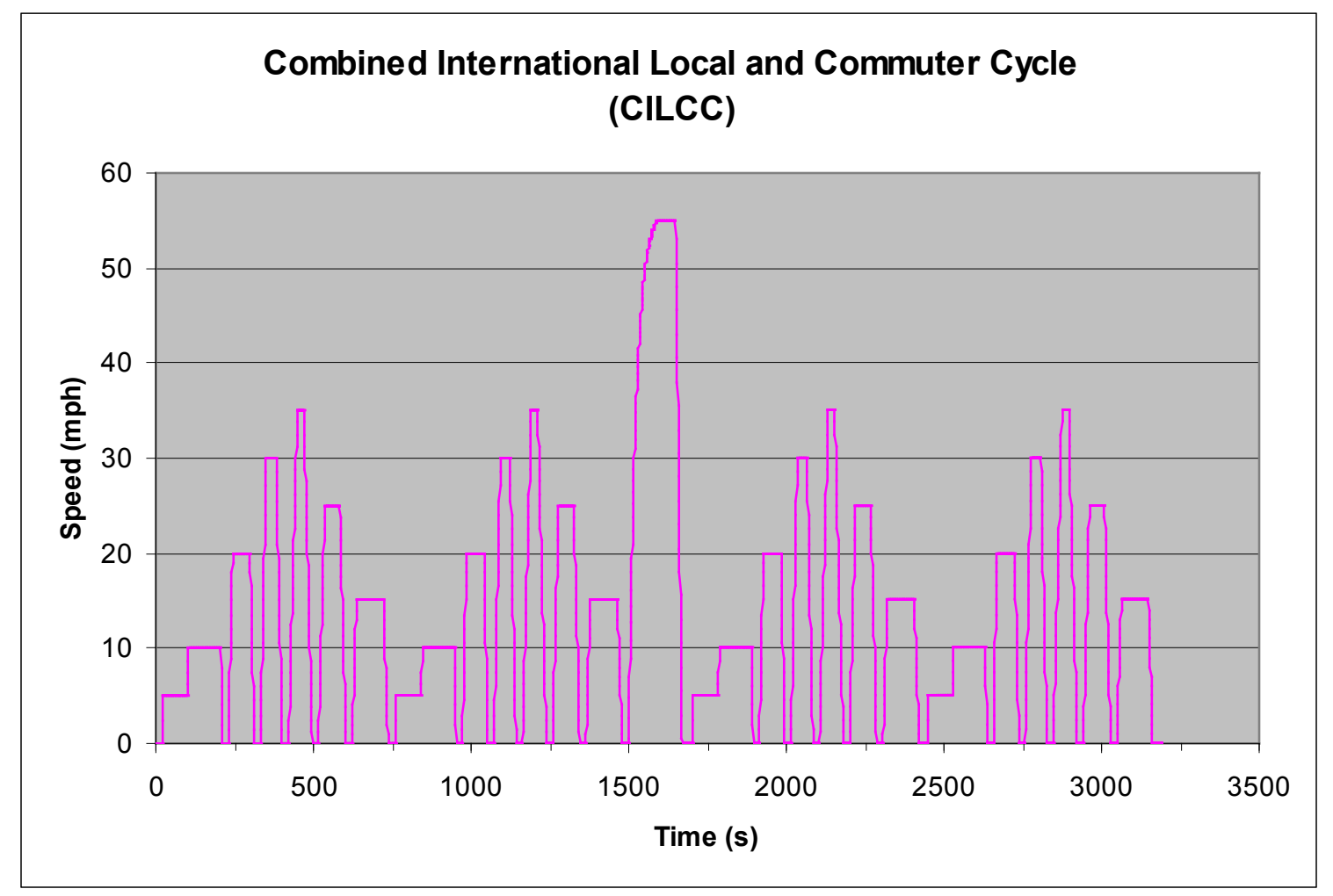

Figure 16. CILCC trace 


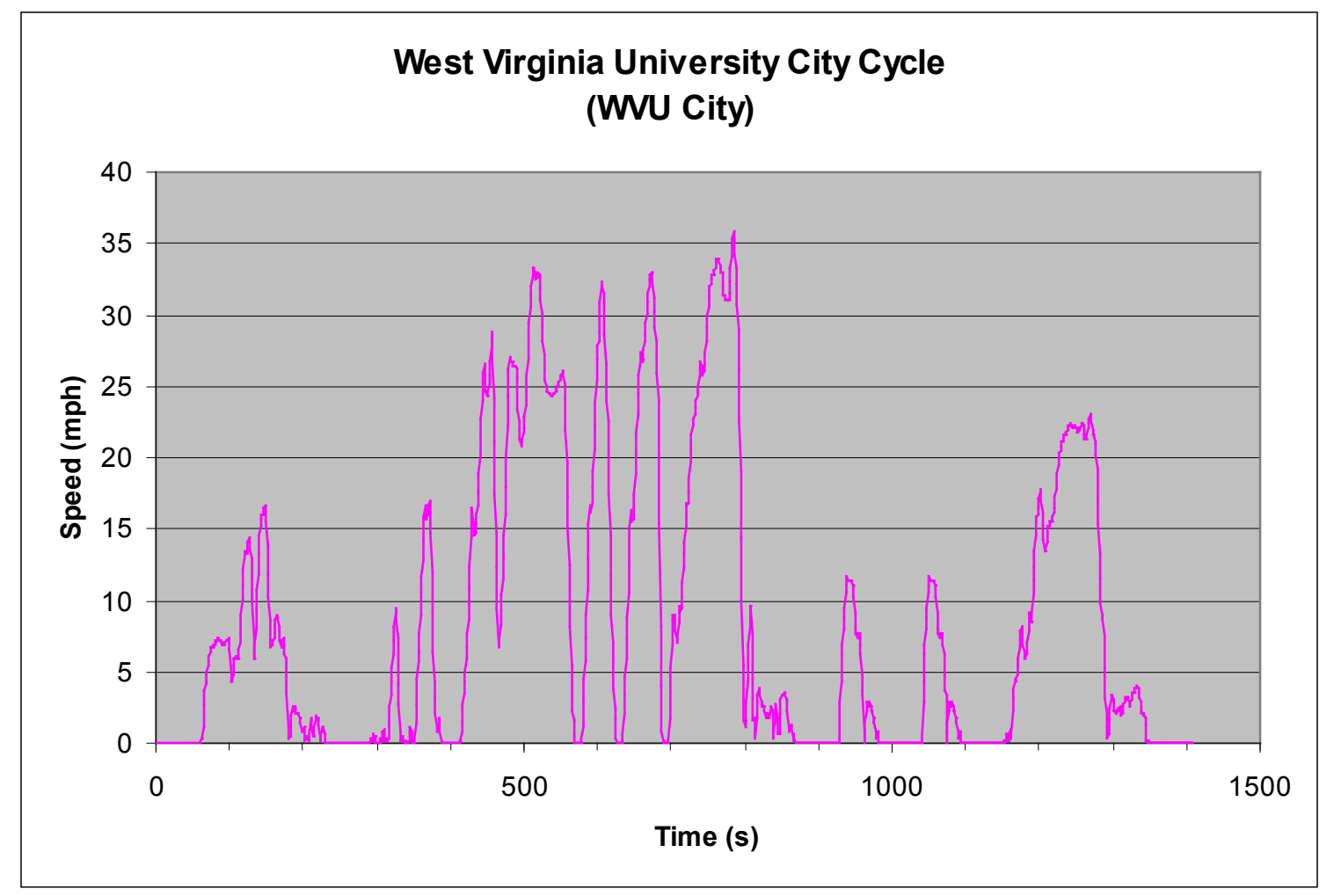

Figure 17. WVU City trace

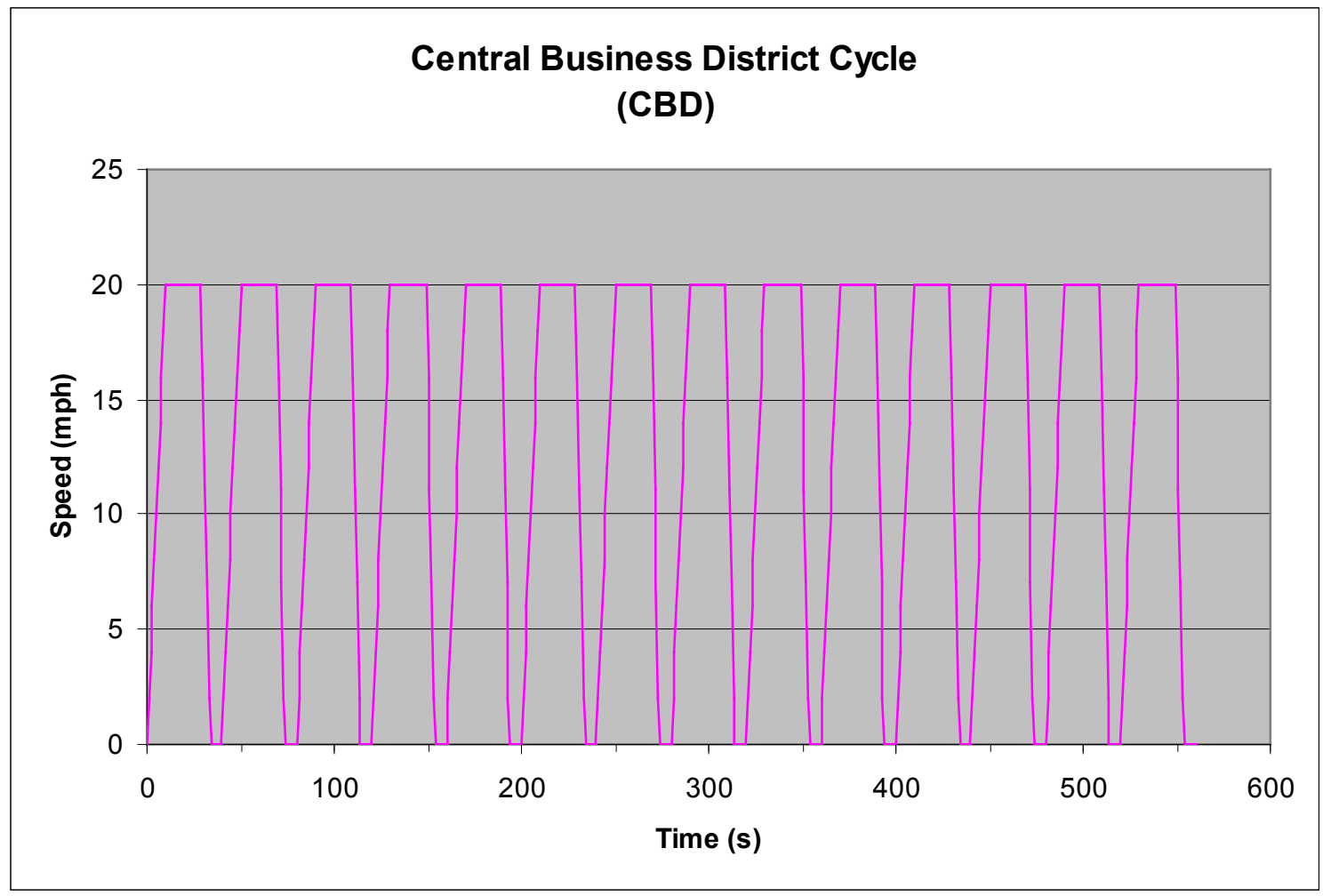

Figure 18. CBD trace 
The test vehicles were installed on the chassis dynamometer shown in Figure 19. All sensors were monitored and recorded continuously by the ReFUEL data acquisition system throughout each test cycle run, unless otherwise noted.

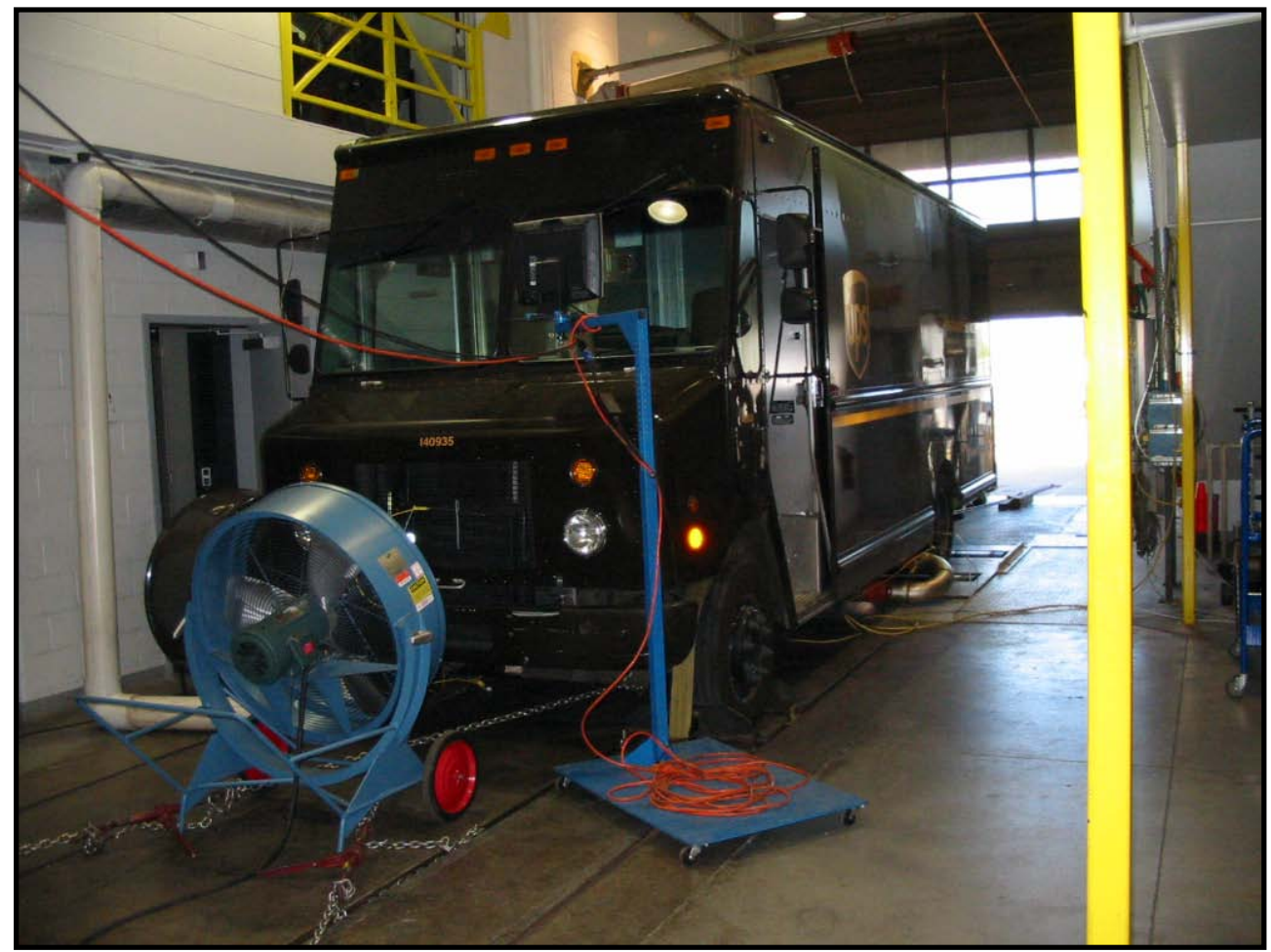

Figure 19. UPS P100 van on NREL's ReFUEL dynamometer

\section{Vehicle Specifications}

Table 10 shows test vehicle information. Due to timing and test vehicle availability, the tests were conducted on Workhorse P100 chassis with VT275 engine - not the same chassis or engine evaluated in this report at the Phoenix location but still the same hybrid system. While the chassis and engine are different, the Eaton hybrid system is the same as the one used on the $\mathrm{P} 70 \mathrm{H}$ chassis. P100 vans are not necessarily assigned to the same type of routes as the P70 vans discussed in the rest of the report.

Table 10. Test Vehicle Information

\begin{tabular}{|l|l|l|l|l|l|l|l|}
\hline & Engine & Transmission & GVWR & $\begin{array}{l}\text { Test } \\
\text { Weight }\end{array}$ & $\begin{array}{l}\text { After- } \\
\text { Treatment }\end{array}$ & Fuel & Chassis \\
\hline $\begin{array}{l}\text { Conventional } \\
\text { P100 }\end{array}$ & $\begin{array}{l}\text { International } \\
\text { VT275 }\end{array}$ & $\begin{array}{l}\text { Allison } \\
\text { Automatic }\end{array}$ & $\begin{array}{l}23,500 \\
\mathrm{lb}\end{array}$ & $\begin{array}{l}17,500 \\
\mathrm{lb}\end{array}$ & $\mathrm{N} / \mathrm{A}$ & Diesel & $\begin{array}{l}\text { Workhorse } \\
\text { P100 }\end{array}$ \\
\hline Hybrid P100 & $\begin{array}{l}\text { International } \\
\text { VT275 }\end{array}$ & $\begin{array}{l}\text { Eaton Parallel } \\
\text { Hybrid } \\
\text { Autoshift }\end{array}$ & $\begin{array}{l}23,500 \\
\mathrm{lb}\end{array}$ & $\begin{array}{l}17,500 \\
\mathrm{lb}\end{array}$ & $\mathrm{N} / \mathrm{A}$ & Diesel & $\begin{array}{l}\text { Workhorse } \\
\text { P100 }\end{array}$ \\
\hline
\end{tabular}




\section{Laboratory Test Results}

All fuel economy and emissions results are averaged from three test runs of each cycle. Fuel economy results for the vans are shown in Table 11 . The hybrid vans showed a $31 \%-37 \%$ improvement in fuel economy over the conventional vans on the tested duty cycles.

Table 11. Fuel Economy of Hybrid and Diesel Van on Various Cycles on Chassis Dynamometer

\begin{tabular}{|l|c|c|c|}
\hline & CILCC & WVU City & CBD \\
\hline $\begin{array}{l}\text { Conventional P100 } \\
\text { (mpg) }\end{array}$ & 9.1 & 6.87 & 6.83 \\
\hline Hybrid P100 (mpg) & 11.99 & 9.38 & 9.16 \\
\hline $\begin{array}{l}\text { Fuel Economy (mpg) \% } \\
\text { increase w/hybrid }\end{array}$ & $31 \%$ & $37 \%$ & $34 \%$ \\
\hline P Value & 0.0010 & 0.0014 & 0.0024 \\
\hline
\end{tabular}

Emissions results for carbon dioxide $\left(\mathrm{CO}_{2}\right)$, oxides of nitrogen $\left(\mathrm{NO}_{\mathrm{x}}\right)$, total hydrocarbons $(\mathrm{THC})$, carbon monoxide (CO), and particulate matter (PM) are shown in Table 12. Results that are not statistically significant at the 95\% confidence level appear in the gray areas. The hybrid vans showed some improvement in emissions, but the results varied significantly depending on the cycle being run. This variation is not unexpected, because the engines operate at different load points with and without the hybrid system. The engine in the hybrid vehicle has not been calibrated for hybrid operation. More consistent improvement in emissions may be possible with hybrid-specific engine calibrations. Heavy-duty engines are certified with an engine certification test but are not certified in chassis.

Table 12. Average Values for Emission Results of Hybrid and Diesel Vans on Specified Cycles

\begin{tabular}{|c|c|c|c|c|c|c|c|c|c|c|c|c|}
\hline & \multicolumn{4}{|c|}{$\overline{\text { CILCC }}$} & \multicolumn{4}{|c|}{ WVU City } & \multicolumn{4}{|c|}{ CBD } \\
\hline & Diesel & Hybrid & $\begin{array}{l}\text { Hybrid } \\
\% \text { diff }\end{array}$ & $\begin{array}{c}P \\
\text { Value }\end{array}$ & Diesel & Hybrid & \begin{tabular}{|l|} 
Hybrid \\
$\%$ diff
\end{tabular} & $\begin{array}{c}P \\
\text { Value }\end{array}$ & Diesel & Hybrid & \begin{tabular}{|l|} 
Hybrid \\
$\%$ diff
\end{tabular} & $\begin{array}{c}P \\
\text { Value }\end{array}$ \\
\hline $\begin{array}{l}\mathrm{CO}_{2} \\
\text { (gram/mile }\end{array}$ & 1026 & 773 & $-25 \%$ & 0.0005 & 1333 & 933 & $-30 \%$ & 0.0001 & 1396 & 1017 & $-27 \%$ & 0.0021 \\
\hline $\begin{array}{l}\mathrm{NO}_{\mathrm{x}} \\
\text { (gram/mile }\end{array}$ & 7.52 & 9.69 & $29 \%$ & 0.0014 & 9.22 & 10.42 & $13 \%$ & 0.0137 & 10.56 & 10.56 & NS & 0.98 \\
\hline $\begin{array}{l}\mathrm{THC} \\
\text { (gram/mile }\end{array}$ & 1.47 & 1.27 & $-14 \%$ & 0.0413 & 3.85 & 3.27 & NS & 0.48 & 1.34 & 1.17 & NS & 0.61 \\
\hline $\begin{array}{l}\mathrm{CO} \\
\text { (gram/mile }\end{array}$ & 7.59 & 5.38 & $-29 \%$ & 0.0025 & 14.31 & 12.07 & $-16 \%$ & 0.0097 & 8.31 & 8.80 & NS & 0.13 \\
\hline $\begin{array}{l}\text { PM } \\
\text { (gram/mile }\end{array}$ & 0.142 & 0.064 & $-55 \%$ & 0.0148 & 0.120 & 0.214 & NS & 0.15 & 0.116 & 0.114 & NS & 0.37 \\
\hline
\end{tabular}

${ }^{*} \mathrm{NS}$ - \% difference is not reported because the $\mathrm{P}$ Value indicates the difference is not statistically significant at the $95 \%$ confidence level

Figure 20 shows emissions and fuel consumption results on the CILCC duty cycle. The hybrid unit produced 25\% less $\mathrm{CO}_{2}, 14 \%$ fewer THC, $29 \%$ less $\mathrm{CO}$, and 55\% fewer PM emissions than the diesel unit did. The hybrid also showed a $29 \%$ increase in $\mathrm{NO}_{\mathrm{x}}$, as well as a $31 \%$ improvement in fuel economy over the cycle. 


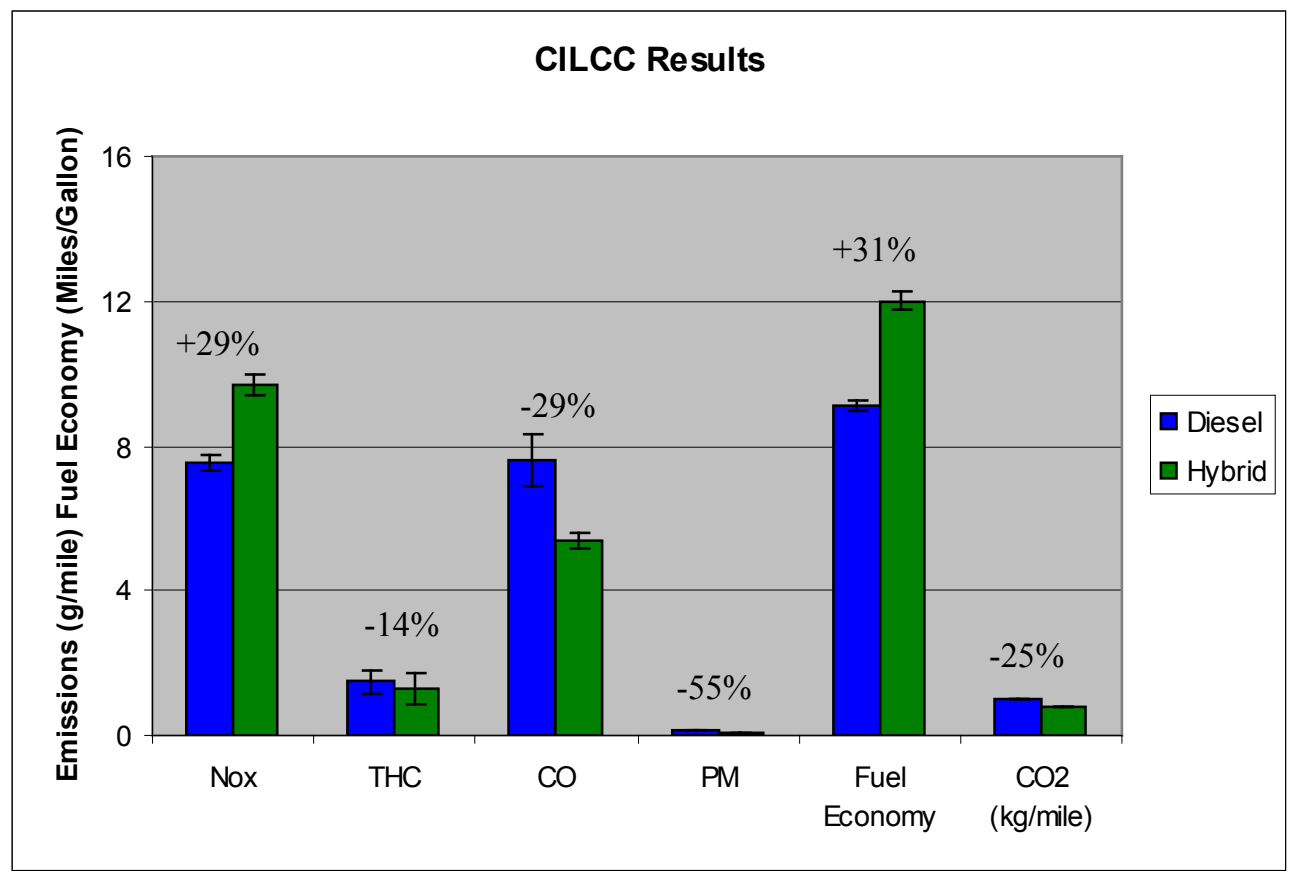

Figure 20. UPS P100 CILCC results

Figure 21 shows emissions and fuel consumption results on the WVU City cycle. The hybrid unit produced $30 \%$ less $\mathrm{CO}_{2}, 16 \%$ less $\mathrm{CO}$, and 13\% more $\mathrm{NO}_{\mathrm{x}}$. The hybrid had a $37 \%$ improvement in fuel economy over this cycle. There was no statistically significant difference in THC or PM emissions.

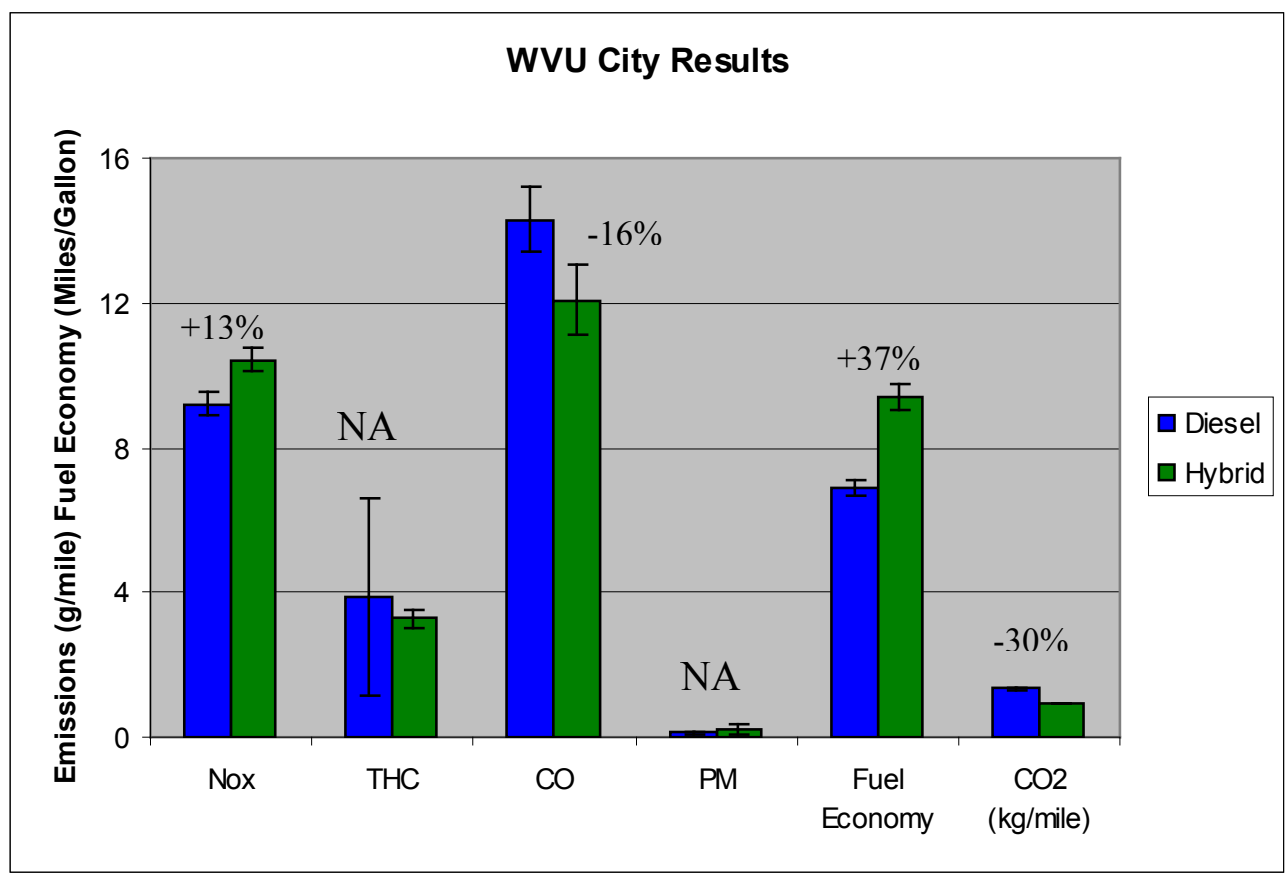

Figure 21. UPS P100 WVU City results 
Figure 22 shows emissions and fuel consumption results on the CBD duty cycle. The hybrid unit produced $27 \%$ less $\mathrm{CO}_{2}$ than the diesel did and showed a 34\% improvement in fuel economy over this cycle. There was no statistically significant difference in THC, CO, PM or $\mathrm{NO}_{\mathrm{x}}$.

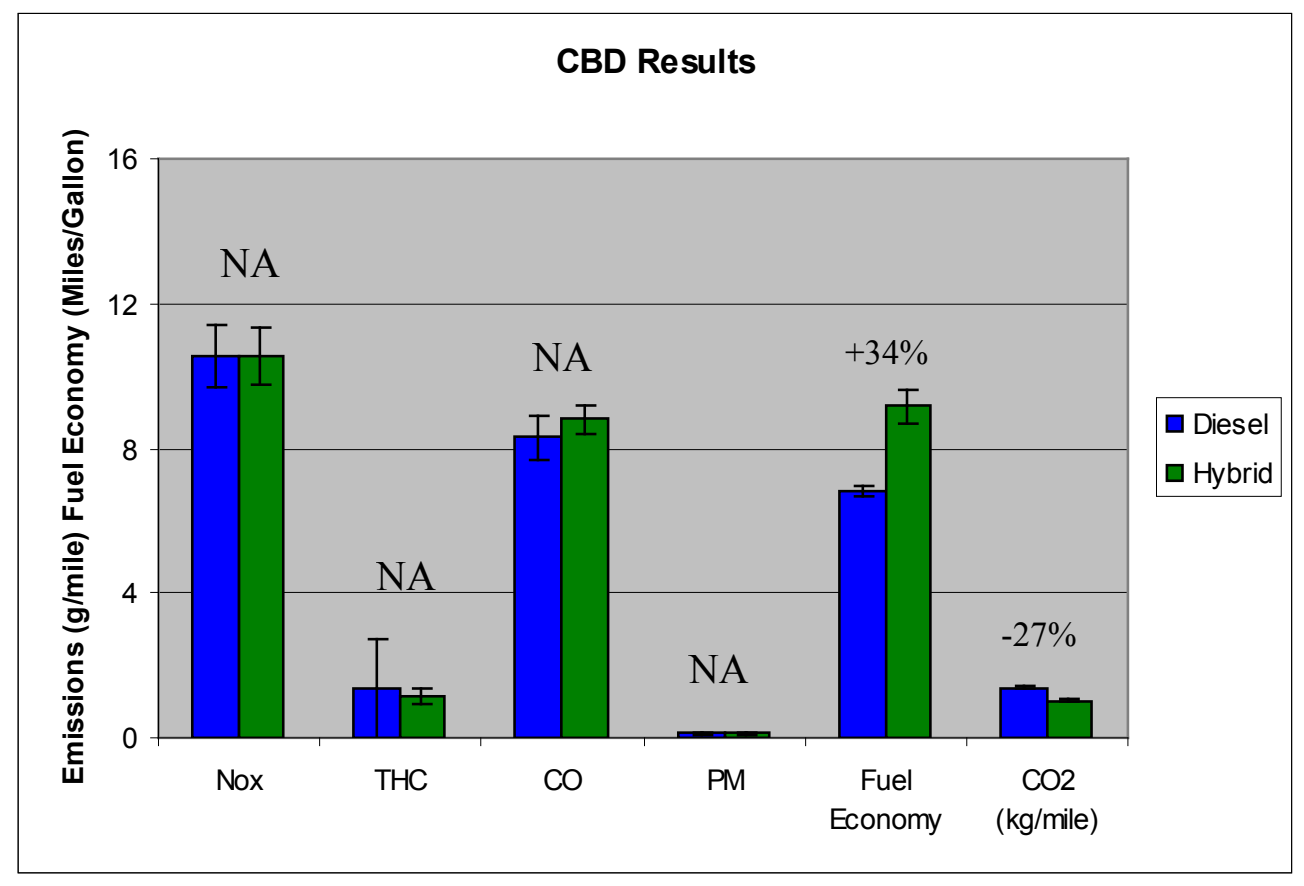

Figure 22. UPS P100 CBD results

\section{Status of UPS Hybrid Fleet}

UPS has been satisfied with the performance of the original 50 (prototype) hybrid electric vans over the first year of service. UPS has ordered an additional 200 hybrids to be deployed in 2009 with additional features and updates.

\section{Conclusions}

- Monthly (and cumulative) miles per van for the hybrids were $20 \%$ lower than they were for the diesels as a result of a more urban duty cycle and lower uptime related to troubleshooting and recalibrating prototype components.

- Miles per operational day were $15 \%$ lower for the hybrids than they were for the diesels. This indicates that the hybrids were assigned more urban routes with more stops per mile and more time spent at slow speeds.

- Fuel economy of the hybrid group was $28.9 \%$ greater than that of the diesel group. Had the diesel group been operating on the same duty cycle as the hybrids, the improvement might have been greater.

- There was no statistically significant difference between the diesel and hybrid groups for total maintenance cost per mile $(\mathrm{P}$ value $=0.82)$.

- There was no statistically significant difference between the diesel and hybrid groups for propulsion maintenance cost per mile $(\mathrm{P}$ value $=0.95)$. 
- Total operating costs per mile for the hybrids were $15 \%$ less than those for the diesels (assuming $\$ 3.80 / \mathrm{gal}$ ).

- Emissions testing generally showed a decrease in $\mathrm{CO}_{2}, \mathrm{THC}, \mathrm{CO}$, and $\mathrm{PM}$ but an increase in $\mathrm{NO}_{\mathrm{x}}$.

- Laboratory fuel economy testing showed a $31 \%$ to $37 \%$ improvement for the hybrids over the diesels. 


\section{Contacts}

\section{U.S. Department of Energy}

Energy Efficiency and Renewable Energy

Vehicle Technologies Program

Lee Slezak

Manager, Advanced Vehicle Testing Activity

Phone: 202-586-2335

E-mail: lee.slezak@ee.doe.gov

National Renewable Energy Laboratory

Mike Lammert

Project Engineer

Phone: 303-275-4067

E-mail: michael.lammert@,nrel.gov

Kevin Walkowicz

Advanced Vehicle Testing Activity Lead

Phone: 303-275-4492

E-mail: kevin.walkowicz@nrel.gov

\section{United Parcel Service}

Robert K. Hall

Director, Maintenance \& Engineering, International Operations

Phone: 404-828-6556

E-mail: rhall@ups.com

Bill Brentar

Automotive Area Manager, Great Basin \& Desert Mountain, Pacific Region

Phone: 602-233-4153

E-mail: bbrentar@ups.com

\section{Eaton Corporation}

Alex Stuckey

Special Projects Engineering

Phone: 269-342-3105

E-mail: AlexBStucky@Eaton.com 


\section{Appendix: Laboratory Description and Test Methods}

\section{General Lab Description}

The vehicles were tested at the ReFUEL Laboratory, which is operated by NREL and located in Denver, Colorado. The lab includes a heavy-duty vehicle (chassis) test cell and an engine dynamometer test cell with emissions measurement capability. Regulated emissions measurements are performed using procedures consistent with SAE J2711. Instrumentation and sensors at the laboratory are maintained with National Institute of Standards and Technology (NIST)-traceable calibration. Test procedures, calibrations, and measurement accuracies are maintained to meet the requirements outlined in the current Code of Federal Regulations (CFR) title 40 , section 86 , subpart N. Data acquisition and combustion analysis equipment are used to measure vehicle performance and emissions. Other capabilities of the laboratory include systems for sampling and analyzing unregulated emissions, on-site fuel storage and fuel blending equipment, high-speed data acquisition hardware and software to support in-cylinder measurements, and fuel ignition quality testing. Instrumentation and sensors at the laboratory are maintained with NIST-traceable calibration.

\section{Chassis Dynamometer}

The ReFUEL Chassis Dynamometer is installed in the main high-bay area of the laboratory. The roll-up door to the high bay is $14 \mathrm{ft} \times 14 \mathrm{ft}$, high enough to accept all highway-ready vehicles without modification. The dynamometer is installed in a pit below the ground level, such that the only exposed part of the dynamometer is the top of the 40-in.-diameter rolls. Two sets of rolls are installed, so that twin-axle tractors can be tested. The distance between the rolls can be varied between $42 \mathrm{in}$. and $56 \mathrm{in}$. The dynamometer will accommodate vehicles with a wheelbase between $89 \mathrm{in}$. and $293 \mathrm{in}$. The dynamometer can simulate up to 80,000-lb vehicles at speeds up to $60 \mathrm{mph}$.

The chassis dynamometer, illustrated in Figure A-1, is composed of three major components: the rolls, which are in direct contact with the vehicle tires during testing; the direct current (DC) electric motor (380 hp absorbing/360 hp motoring) dynamometer; and the flywheels.

The rolls are the means by which power is absorbed from the vehicle. The rolls are attached to gearboxes that increase the speed of the central shaft by a factor of 5 . The flywheels, mounted on the back of the dynamometer, provide a mechanical simulation of the vehicle inertia.

The electric motor is mounted on trunnion bearings and is used to measure the shaft torque from the rolls. The energy absorption capability of the dynamometer is used to apply the "road load," which is a summation of the aerodynamic drag and friction losses that the vehicle experiences in use, as a function of speed. The road load may be determined experimentally if data are available or estimated from standard equations. The electric dynamometer is also used to adjust the simulated inertia, either higher or lower than the 31,000-lb base dynamometer inertia, as the test plan requires. The inertia simulation range of the chassis dynamometer is $8,000-80,000 \mathrm{lb}$. The electric motor may also be used to simulate grades and provide braking assist during decelerations.

The test vehicle is secured with the drive axles over the rolls. A driver's aid monitor in the cab is used to guide the vehicle operator in driving the test trace. A large fan may be used to cool the vehicle radiator during testing. The chassis dynamometer is supported by 72 channels of data 
acquisition in addition to the emissions measurement, fuel metering, and combustion analysis subsystems.

The dynamometer is capable of simulating vehicle inertia and road load during drive cycle testing. When the vehicle is jacked up off the rolls, an automated dynamometer warm-up procedure is performed daily, prior to testing, to ensure that parasitic losses in the dynamometer and gearboxes have stabilized at the appropriate level to provide repeatable loading. An unloaded coast-down procedure is also conducted to confirm that inertia and road load are being simulated by the dynamometer control system accurately. Between test runs, a loaded coast-down procedure is performed to further ensure the stability of vehicle and dynamometer parasitic losses and accurate road load simulation during testing.

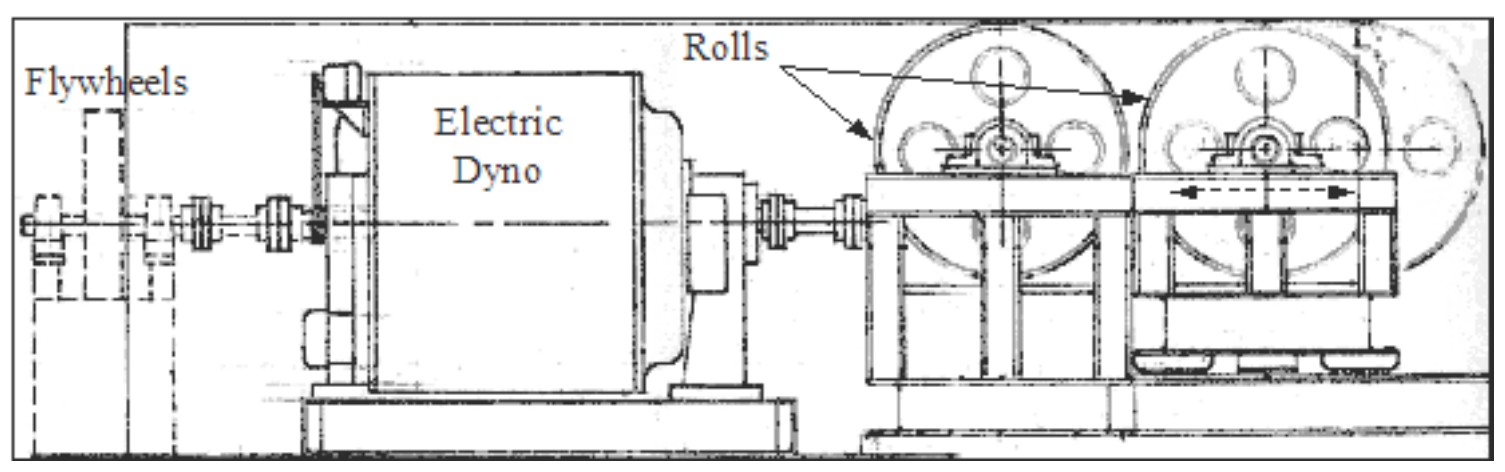

Figure A-1. Chassis dynamometer schematic

\section{Fuel Storage and Blending}

There are buildings designed specifically for safely storing and handling fuels at the ReFUEL facility. The fuel storage shed is $8 \mathrm{ft} \times 26 \mathrm{ft}$ and holds up to 48 drums ( 55 gal. each). Features include heating/cooling, secondary containment to $25 \%$ of capacity, continuous ventilation, explosion-proof wiring/lighting, and a dry chemical fire suppression system.

The fuel blending shed is $8 \mathrm{ft} \times 14 \mathrm{ft}$ and has a nominal storage capacity of 24 drums. It has all of the features of the storage shed plus explosion-proof electrical outlets for powering accessories. The fuel blending can be performed on a gravimetric or volumetric basis, with capability for both large-scale $(\mathrm{L} / \mathrm{kg})$ and small-scale (cc/g) measurements.

A fuel line inside a sealed conduit delivers the fuel from the supply drum to the fuel metering/conditioning system inside the ReFUEL laboratory, eliminating the need for bulk fuel storage inside the laboratory. Another fuel line in the same conduit delivers waste fuel back to the fuel blending shed for storage (waste fuel is generated only when a fuel changeover requires a flush of the system). 


\section{Fuel Metering and Conditioning}

The fuel metering and conditioning system (Figure A2) supports test work for both the engine and the chassis dynamometers. The meter measures volumetric flow to an accuracy of $\pm 0.5 \%$ of the reading, with a manufacturer's stated reproducibility of $0.2 \%$. An inline sensor measures the density with an accuracy of $\pm 0.001 \mathrm{~g} / \mathrm{cc}$, allowing an accurate mass measurement over the test cycle even if the density of the fuel blend is not known prior to testing.

\section{Air Handling and Conditioning}

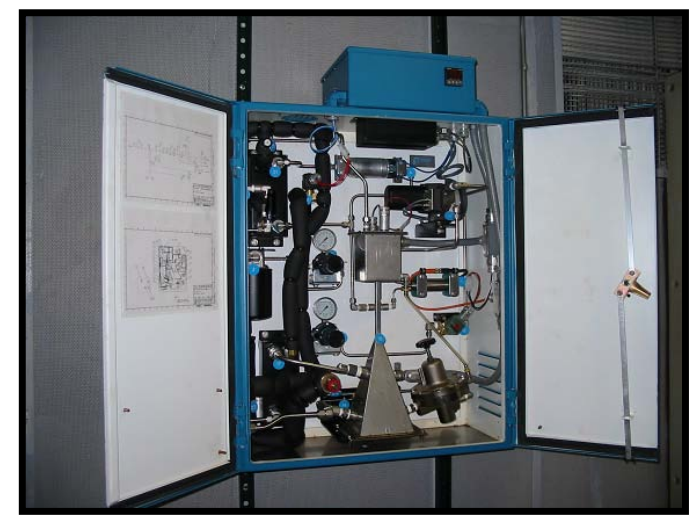

Dilution air and the air supplied to the test engine or vehicle for combustion are derived from a common source, a roof-mounted system that conditions the temperature of the air and humidifies as needed to meet desired specifications. The system can also pressurize the incoming air to simulate sea level combustion. This gives the lab the ability to simulate any altitude between sea level and $5280 \mathrm{ft}$. This air is passed through a HEPA filter, in accordance with 2007 CFR specifications, to eliminate background particulate matter as a source of uncertainty in particulate measurements. The average inlet air temperature to the vehicle is maintained within a window of $75^{\circ} \mathrm{F} \pm 4^{\circ} \mathrm{F}$ for all test runs, and average humidity is controlled to 75 grains $/ \mathrm{lb}$ (absolute) \pm 4 grains $/ \mathrm{lb}$.

\section{Emissions Measurement}

The ReFUEL Laboratory's emissions measurement system supports both the engine and chassis dynamometers. It is based on the full-scale exhaust dilution tunnel method with a constant volume sampling (CVS) system for mass flow measurement. The system is designed to comply with the requirements of 2007 CFR, title 40, part 86, subpart N. Exhaust from the engine or vehicle flows through insulated piping to the full-scale 18-in.-diameter stainless steel dilution tunnel. A static mixer ensures thorough mixing of exhaust with conditioned, filtered, dilution air prior to sampling of the dilute exhaust stream to measure gaseous and particulate emissions.

A system with three venturi nozzles (Figure A-3) is employed to maximize the flexibility of the emissions measurement system. Featuring 500 cubic feet per minute (cfm), $1000 \mathrm{cfm}$, and $1500 \mathrm{cfm}$ venturi nozzles and gas-tight valves, the system flow can be varied from $500 \mathrm{cfm}$ to $3000 \mathrm{cfm}$ flow rates in $500 \mathrm{cfm}$ increments.

This allows the dilution level to be tailored to the engine size being tested (whether on the engine stand or in a

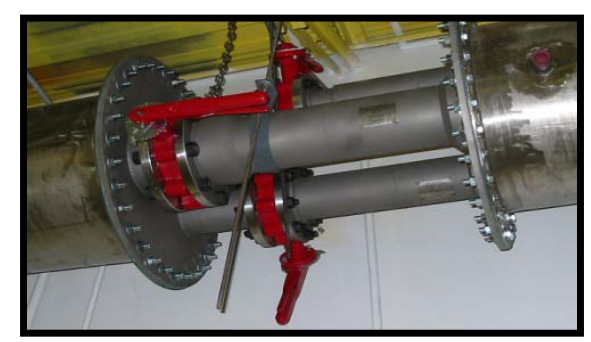

Figure A-3. Venturi nozzles vehicle), maximizing the accuracy of the emissions measurement equipment.

The gaseous emissions bench is a Pierburg model AMA-2000 (Figure A-4, center). It features continuous analyzers for $\mathrm{THC}, \mathrm{NO}_{\mathrm{x}}, \mathrm{CO}, \mathrm{CO}_{2}$, and $\mathrm{O}_{2}$. The system also features auto-ranging, automated calibration, zero check, and span check features as well as integrating functions for calculating cycle emissions. It communicates with the ReFUEL data acquisition systems through a serial interface. 
There are two heated sample trains for gaseous emissions measurement: one for $\mathrm{HC}$ and another for the other gaseous emissions. The $\mathrm{NO}_{\mathrm{x}}$ and $\mathrm{HC}$ measurements are performed on a wet basis, while $\mathrm{CO}$, $\mathrm{CO}_{2}$, and $\mathrm{O}_{2}$ are measured on a dry basis. Sample probes are located in the same plane in the dilution tunnel.

The particulate matter sample control bench, shown in Figure A-4, is managed by the ReFUEL data acquisition system through a serial connection. It maintains a desired sample flow rate through the particulate matter (PM) filters in proportion to the overall CVS flow, in accordance with the CFR. Stainless steel filter holders, designed to the 2007 CFR requirements (Figure A-5, center), house 47-mm-diameter Teflon membrane filters through which the dilute exhaust sample flows. The PM sampling system is capable of drawing a

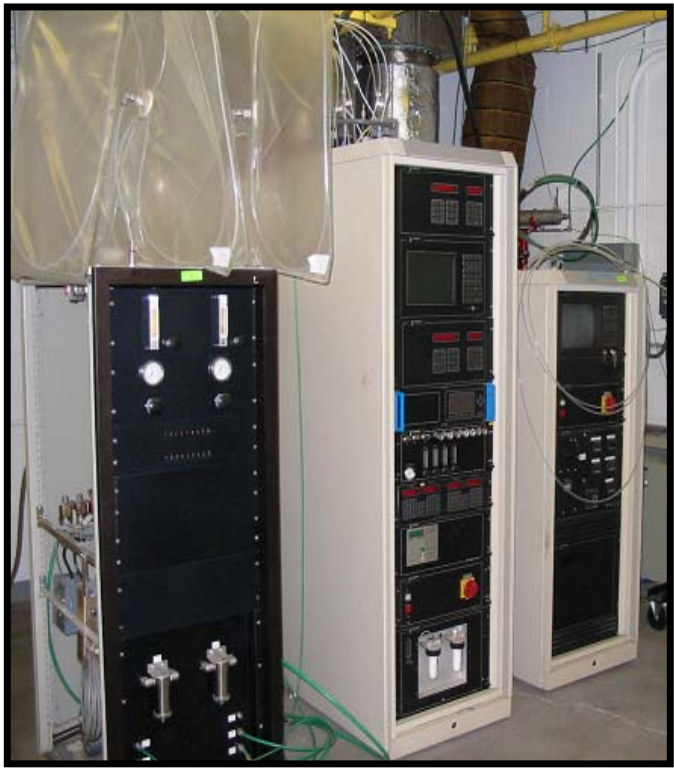

Figure A-4. Emissions bench sample directly from the large full-scale dilution tunnel or utilizing secondary dilution to achieve the desired temperature, flow, and concentration characteristics. A cyclone separator, as described in the CFR requirements, is employed to mitigate tunnel PM artifacts.

A dedicated clean room/environmental chamber (Figure A-5, left) is inside the ReFUEL facility. It is a Class 1000 clean room with precise control over the temperature and humidity $\left( \pm 1^{\circ} \mathrm{C}\right.$ for temperature and dew point). This room is used for all filter handling, conditioning, and weighing.
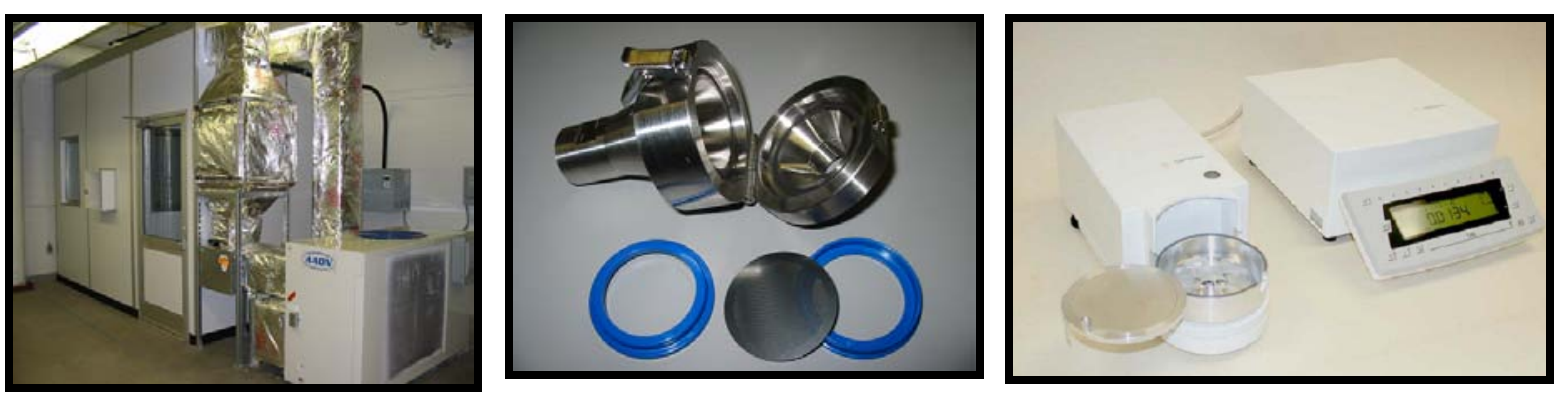

Figure A-5. Class 1000 clean room, filter housing, and microbalance

The microbalance (Figure A-5, right) for weighing PM filters has a readability of $0.1 \mu \mathrm{g}$ (a CFR requirement) and features a barcode reader for filter identification and tracking and a computer interface for data acquisition. The microbalance is installed on a specially designed table to eliminate variation in the measurement due to vibration. The microbalance manufacturer (Sartorius) was consulted on the design of the clean room, to ensure that the room air flow would be compatible with the microbalance. 


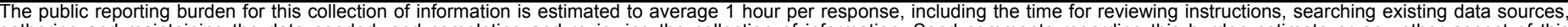

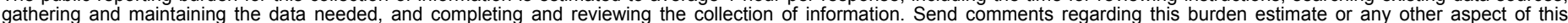

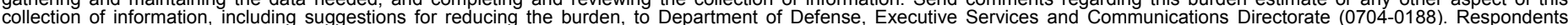

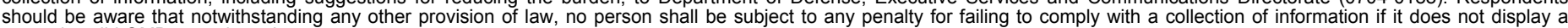

should be aware that notwithstanding

PLEASE DO NOT RETURN YOUR FORM TO THE ABOVE ORGANIZATION.

\begin{tabular}{l|l|l|}
\hline 1. REPORT DATE $(D D-M M-Y Y Y Y)$ & 2. REPORT TYPE & 3. DATES COVERED (FrOm - TO)
\end{tabular}

December 2009

Technical Report

4. TITLE AND SUBTITLE

Twelve-Month Evaluation of UPS Diesel Hybrid Electric Delivery

Vans 5a. CONTRACT NUMBER

DE-AC36-08-GO28308

5b. GRANT NUMBER

5c. PROGRAM ELEMENT NUMBER

5d. PROJECT NUMBER

NREL/TP-540-44134

5e. TASK NUMBER

FC08.3000

5f. WORK UNIT NUMBER
7. PERFORMING ORGANIZATION NAME(S) AND ADDRESS(ES)

National Renewable Energy Laboratory

1617 Cole Blvd.

Golden, CO 80401-3393

9. SPONSORING/MONITORING AGENCY NAME(S) AND ADDRESS(ES)
8. PERFORMING ORGANIZATION REPORT NUMBER

NREL/TP-540-44134
10. SPONSOR/MONITOR'S ACRONYM(S) NREL

11. SPONSORING/MONITORING AGENCY REPORT NUMBER

12. DISTRIBUTION AVAILABILITY STATEMENT

National Technical Information Service

U.S. Department of Commerce

5285 Port Royal Road

Springfield, VA 22161

13. SUPPLEMENTARY NOTES

14. ABSTRACT (Maximum 200 Words)

This 12-month evaluation is part of a series of evaluations from the U.S. Department of Energy. Through the National Renewable Energy Laboratory (NREL), DOE has been tracking and evaluating new propulsion systems in transit buses and trucks. This report focuses on a parallel hybrid-electric diesel delivery van propulsion system operated by United Parcel Service. The propulsion system is an alternative to the standard diesel system and could enable reductions in emissions, primarily particulate matter and oxides of nitrogen, as well as reductions in petroleum use. Hybrid propulsion allows for increased fuel economy, which ultimately reduces petroleum use.

15. SUBJECT TERMS

fuel economy; fuel savings; emissions reduction; hybrid electric diesel trucks; medium duty hybrid vehicles; United Parcel Service; NREL

16. SECURITY CLASSIFICATION OF:

\begin{tabular}{l|l|l}
\hline a. REPORT & b. ABSTRACT & c. THIS PAGE \\
Unclassified & Unclassified & Unclassified
\end{tabular}

19a. NAME OF RESPONSIBLE PERSON

19b. TELEPHONE NUMBER (Include area code) 